\section{BUDGET}

PERSPECTIVES 2022

PAPER 2

JUNE 2021

\section{COVID-19 AND THE IRISH WELFARE SYSTEM}

\section{CLAIRE KEANE, KARINA DOORLEY AND DORA TUDA}

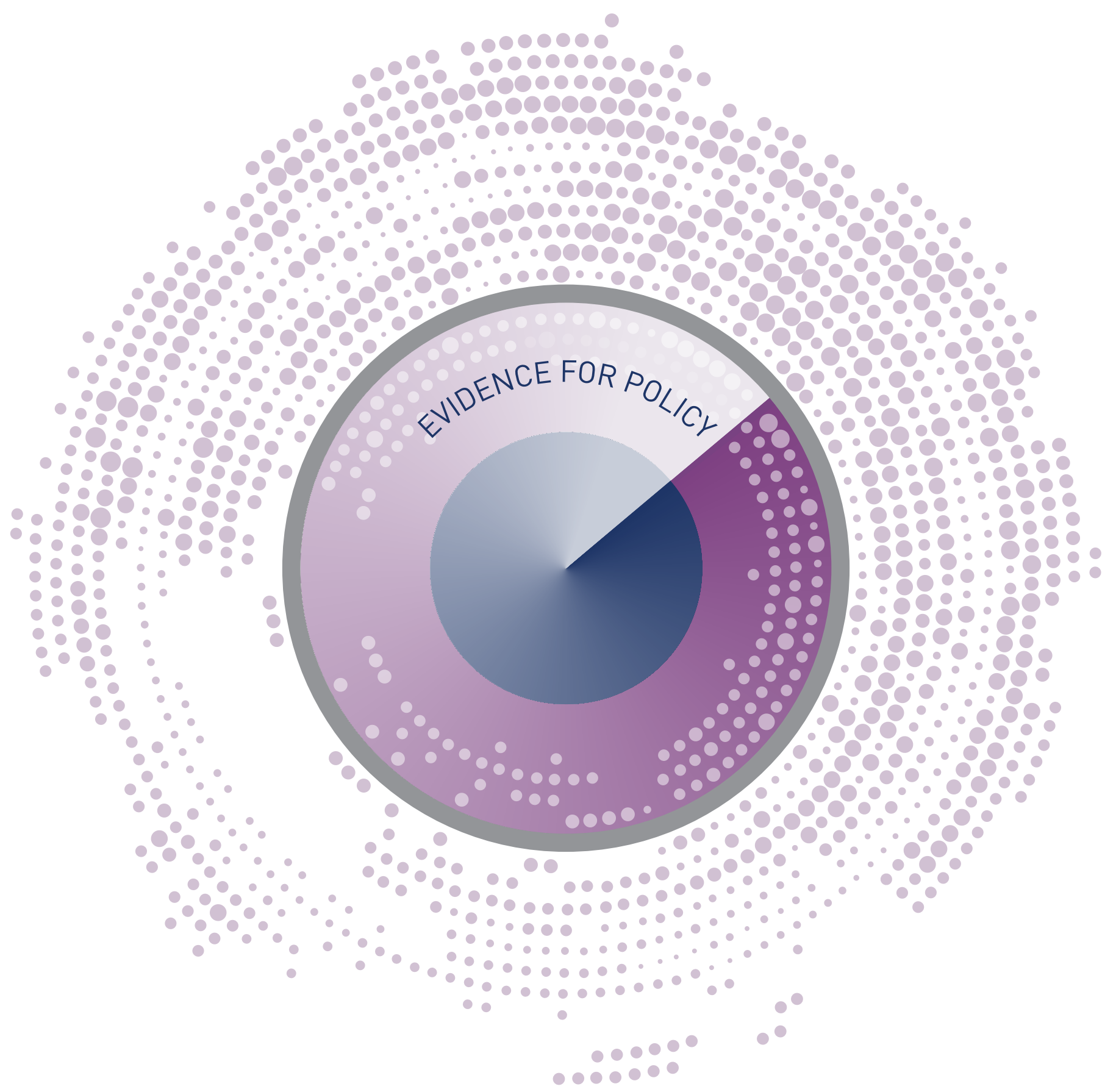




\title{
COVID-19 AND THE IRISH WELFARE SYSTEM
}

\author{
Claire Keane
}

Karina Doorley

Dora Tuda

June 2021

\section{BUDGET PERSPECTIVES 2022}

\section{PAPER 2}

Available to download from www.esri.ie

https://doi.org/10.26504/bp20222

(C) 2021 The Economic and Social Research Institute Whitaker Square, Sir John Rogerson's Quay, Dublin 2

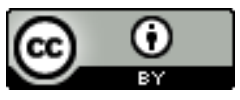

This Open Access work is licensed under a Creative Commons Attribution 4.0 International License (https://creativecommons.org/licenses/by/4.0/), which permits unrestricted use, distribution, and reproduction in any medium, provided the original work is properly credited. 



\section{ABOUT THE ESRI}

The mission of the Economic and Social Research Institute is to advance evidencebased policymaking that supports economic sustainability and social progress in Ireland. ESRI researchers apply the highest standards of academic excellence to challenges facing policymakers, focusing on 12 areas of critical importance to 21st Century Ireland.

The Institute was founded in 1960 by a group of senior civil servants led by Dr T.K. Whitaker, who identified the need for independent and in-depth research analysis to provide a robust evidence base for policymaking in Ireland.

Since then, the Institute has remained committed to independent research and its work is free of any expressed ideology or political position. The Institute publishes all research reaching the appropriate academic standard, irrespective of its findings or who funds the research.

The quality of its research output is guaranteed by a rigorous peer review process. ESRI researchers are experts in their fields and are committed to producing work that meets the highest academic standards and practices.

The work of the Institute is disseminated widely in books, journal articles and reports. ESRI publications are available to download, free of charge, from its website. Additionally, ESRI staff communicate research findings at regular conferences and seminars.

The ESRI is a company limited by guarantee, answerable to its members and governed by a Council, comprising 14 members who represent a cross-section of ESRI members from academia, civil services, state agencies, businesses and civil society. The Institute receives an annual grant-in-aid from the Department of Public Expenditure and Reform to support the scientific and public interest elements of the Institute's activities; the grant accounted for an average of 30 per cent of the Institute's income over the lifetime of the last Research Strategy. The remaining funding comes from research programmes supported by government departments and agencies, public bodies and competitive research programmes.

Further information is available at www.esri.ie 


\section{THE AUTHORS}

Dr Claire Keane and Dr Karina Doorley are Senior Research Officers at the ESRI and Adjunct Associate Professors at TCD. Dr Dora Tuda is a Postdoctoral Research Fellow at the ESRI and an Adjunct Assistant Professor at TCD.

\section{ACKNOWLEDGEMENTS}

We are grateful to the Central Statistics Office for providing access to the Survey of Income and Living Conditions, on which the SWITCH tax-benefit model is based, and the Labour Force Survey. SWITCH is based on the EUROMOD platform. Originally maintained, developed and managed by the Institute for Social and Economic Research (ISER), since 2021 EUROMOD is maintained, developed and managed by the Joint Research Centre (JRC) of the European Commission, in collaboration with EUROSTAT and national teams from the EU countries. We are indebted to the many people who have contributed to the development of EUROMOD. This work was carried out with funding from the ESRI's Tax, Welfare and Pensions Research Programme - supported by the Departments of Public Expenditure and Reform; Employment Affairs and Social Protection; Health; Children and Youth Affairs; and Finance - which is gratefully acknowledged. We thank Alyvia McTague for research assistance.

This paper has been accepted for publication by the Institute, which does not itself take institutional policy positions. The paper has been peer-reviewed prior to publication. The authors are solely responsible for the content and the views expressed. 


\section{TABLE OF CONTENTS}

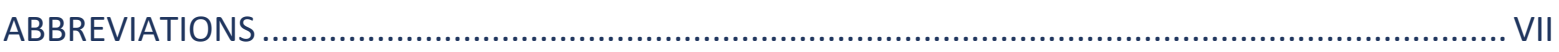

ABSTRACT

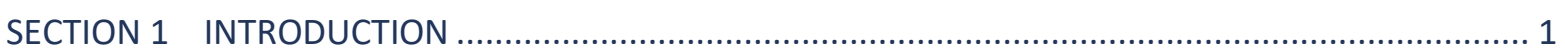

SECTION 2 THE COVID-19 PANDEMIC AND THE POLICY RESPONSE …........................................ 3

SECTION 3 THE EFFECT OF PANDEMIC-RELATED UNEMPLOYMENT .......................................... 7

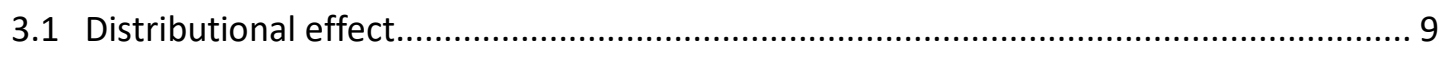

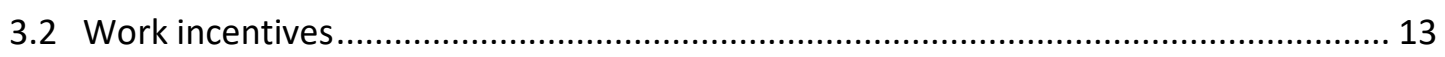

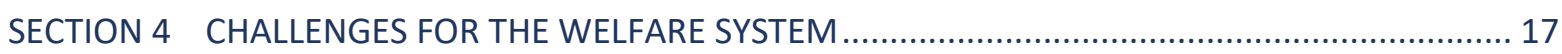

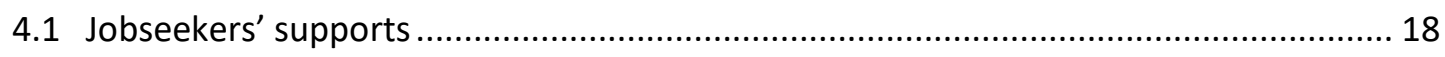

4.2 Underemployment and in-work supports............................................................... 22

4.3 Employment subsidies and short-time work.......................................................... 25

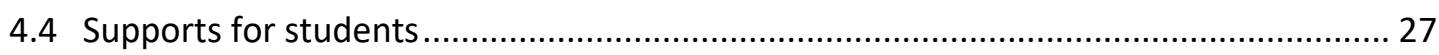

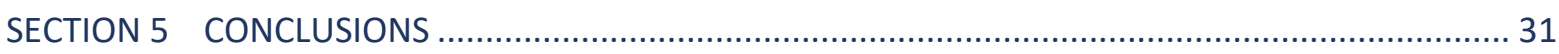

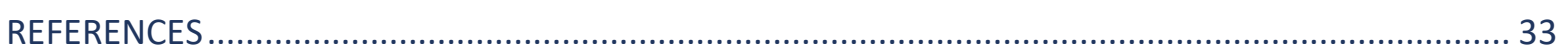

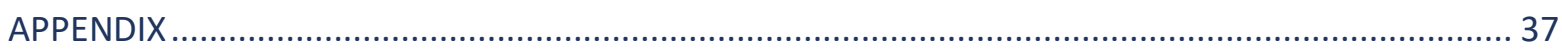




\section{LIST OF TABLES}

Table 3.1 A profile of working-age adults who lose disposable income and lose more than 20 per cent of disposable income as a result of pandemic-related job loss in the absence of the PUP and EWSS.

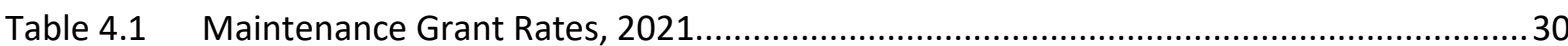

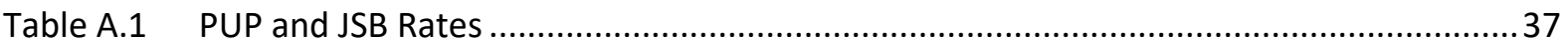

\section{LIST OF FIGURES}

Figure 2.1 Unemployment rate, standard and COVID-19 adjusted ..............................................5

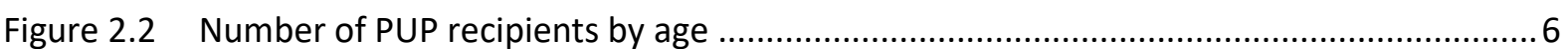

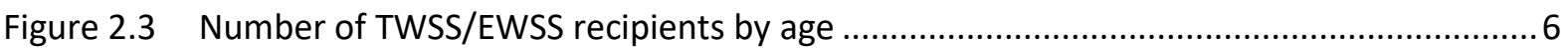

Figure 3.1 Distributional effect of employment losses with and without COVID-19 policies...........10

Figure 3.2 Estimated replacement rate (left) and participation tax rate (right) of the newly unemployed

Figure 4.1 Distributional effect of employment losses with and without COVID-19 policies and JSA Reform.

Figure 4.2 Part-time employment, total and involuntary

Figure 4.3 Distributional effect of employment losses with and without COVID-19 policies and WFP Reform 


\section{ABBREVIATIONS}

CSO

DSP

EWSS

IQA

IQC

$J R$

JSA

JSB

LFS

METRs

OPFP

PRSI

PTR

PUP

RR

SILC

STW

STWS

SWITCH

TWSS

UA

USC

WFP
Central Statistics Office

Department of Social Protection

Employment Wage Subsidy scheme

Increase for Qualified Adult

Increase for Qualified Child

Job retention

Jobseeker's Allowance

Jobseeker's Benefit

Labour Force Survey

Marginal effective tax rates

One Parent Family Payment

Pay-Related Social Insurance

Participation tax rate

Pandemic Unemployment Payment

Replacement rate

Survey of Income and Living Conditions

Short-time work

Short-Time Work Support

Simulating Welfare and Income Tax Changes

Temporary Wage Subsidy scheme

Unemployment Assistance

Universal Social Charge

Working Family Payment 



\section{ABSTRACT}

COVID-19 had, and continues to have, a strong negative effect on incomes in Ireland due to widespread job losses as the measures put in place to slow the spread of the disease resulted in severe economic restrictions. Despite the existence of unemployment supports, additional income supports were introduced to protect incomes. As public health restrictions lift and the economy recovers, we face the withdrawal of such supports. We examine these supports and the role they played in supporting incomes. By profiling those who benefitted most from the new schemes, we highlight the groups most at risk of significant income losses as they wind down. We consider what gaps in the social welfare system necessitated the introduction of such schemes in the first place, along with potential future policy changes to ensure that the social welfare system can provide adequate income protection and financial incentives to work as we emerge from the COVID-19 crisis. 



\section{SECTION 1}

\section{Introduction}

The COVID-19 crisis has had a strong impact on many families in Ireland. Job losses and reductions in income have been commonplace. The Irish welfare system, like that in most countries, faced huge challenges in responding to the crisis. Despite having welfare schemes in place for unemployment, additional measures were implemented to ensure an adequate safety net for those who lost their jobs and to bolster labour-market attachment for workers who could not work remotely and whose workplace was forced to close to help halt the spread of COVID-19.

As we emerge from the crisis, the emergency welfare policies put in place have highlighted issues in the social welfare system in Ireland that necessitated their introduction. While some measures are specifically related to the virus, such as the Enhanced Illness Benefit, the introduction of other benefits highlights the existence of groups that would not have been entitled to a pre-existing unemployment benefit, or for whom the rate of payment of this benefit was not considered adequate to maintain living standards. The Pandemic Unemployment Payment (PUP) was introduced to protect the incomes of those who lost their jobs due to the pandemic. It was set at a higher rate than the personal rate of existing unemployment supports and is payable to a wider group of people. The rates are set to be reduced to bring them more in line with pre-existing unemployment supports in September and to be abolished entirely in February 2022. The payment will cease in September 2021 for full-time students. The initial wage subsidy scheme, the Temporary Wage Subsidy scheme (TWSS), was introduced in March 2020 and replaced by the Employment Wage Subsidy scheme (EWSS). This scheme allows employers to claim subsidies for eligible employees and keep them on their payroll, with or without topping their income up to its pre-pandemic level. On 1 June 2021, the Government announced that the EWSS would be withdrawn in December 2021. ${ }^{1}$

Despite the recent easing of restrictions and gradual reopening of the economy, it is anticipated that unemployment will remain elevated in 2021 and into 2022. In addition, the Great Recession has shown us that certain groups, particularly the young, can feel the effects of unemployment for many years. Despite the investment in social welfare schemes across OECD countries during the pandemic, a recent OECD survey (OECD, 2021) highlights worries about health and economic security and a larger demand by citizens for government support. Many countries 
show increased willingness to pay more taxes to fund such public supports. Ireland is no exception - more than two-thirds of Irish people want the Government to do more to protect their economic and social security, close to the OECD average.

In this paper we examine the tax-benefit schemes implemented in response to COVID-19 in Ireland. We show the impact that COVID-19 has had on the incomes of families and to what extent the existing social welfare system helped to protect people's incomes, as well as the income protection provided by the newly introduced supports. There has been much public debate around the PUP and its potential to reduce financial incentives to work. In this research, we provide concrete evidence around these financial work incentives. Given that schemes such as the PUP are to be wound down in the coming months, we highlight some issues that have been exposed in the social welfare system and examine some potential policy reforms that could help tackle some of the issues highlighted.

Section 2 discusses the COVID-19 pandemic, its impact on employment in Ireland and the associated welfare policy responses. Section 3 examines the impact of COVID-19 on family incomes, the extent to which the existing welfare system protected those incomes, and the additional income protection provided by the new COVID-specific supports, such as the PUP and wage subsidy. It also examines the effect of the PUP on work incentives. Section 4 discusses some issues that the pandemic has exposed relating to current income supports, as well as the international evidence relating to employment subsidies. It also examines some potential reforms that could be put in place to address some of the welfare issues faced. Section 5 concludes. 


\section{SECTION 2}

\section{The COVID-19 pandemic and the policy response}

The first case of COVID-19 in Ireland was confirmed on 29 February 2020. The first lockdown occurred soon afterwards, on 12 March. This resulted in huge loss of employment in many sectors of the economy. The PUP, announced on the same day, was initially set at a flat rate of $€ 203$ per week, the same rate as the maximum personal rate for the main existing unemployment payments. However, no contribution history was required to claim the PUP (unlike with the contributory unemployment benefit, Jobseeker's Benefit - JSB) and the payment was not subject to a means test (like the non-contributory unemployment benefit, Jobseeker's Allowance - JSA). In addition, no increases for dependent adults or children are awarded with the PUP, unlike with traditional social welfare payments. As a consequence, some families who suffered job losses were actually better off claiming JSB or JSA rather than the PUP - and did so.

The rate of the PUP increased to $€ 350$ per week on 24 March 2020 'in recognition of the fact that so many fellow citizens have lost their jobs so suddenly'. The stated rationale for the $€ 350$ rate was that this was approximately 75 per cent of average earnings in the sectors most affected. ${ }^{2}$ The rate was changed a number of times in the following months amid claims that some recipients were better off on the PUP than before the pandemic. Currently, the PUP is a four-tier benefit; claimants are entitled to $€ 203$, $€ 250$, $€ 300$ or $€ 350$ per week, depending on their pre-pandemic earnings. The rates are set to reduce in September, aligning them more closely with JSB and JSA rates.

On 19 March 2020, in an attempt to help maintain links between employers and employees, the Employer Refund Scheme was introduced. This allowed employees to remain on company payrolls while receiving a state support payment. This scheme was replaced by the Temporary Wage Subsidy scheme (TWSS) on 26 March. The TWSS allowed employers to claim subsidies of up to $€ 410$ per week for eligible employees that were kept on the payroll. On 1 September, the TWSS was replaced by the Employment Wage Subsidy scheme (EWSS), which provides a flat-rate subsidy per employee to employers who have suffered at least a 30 per cent loss in turnover. In contrast to the furlough scheme in the UK, workers in receipt of the TWSS or EWSS were permitted to continue working. This increased the potential for deadweight losses - whereby employees who would have been kept on in the absence of the scheme were subsidised - but also allowed firms to continue operating below full capacity. A number of tiered rates were added to this scheme in October 2020, to keep the generosity of the scheme in line with the 
PUP. The subsidy currently ranges between $€ 203$ and $€ 350$ per week, depending on the gross income of the employee. This scheme is also set to be withdrawn in December 2021.

A third major measure introduced in response to the pandemic was Enhanced Illness Benefit for COVID-19. The traditional waiting period of six days for Illness Benefit was abolished for those who contract COVID-19 or are required to selfisolate, and the rate of the benefit was increased from $€ 203$ to $€ 350$ per week.

The economy was cautiously reopened during the summer of 2020 but a second wave of the virus led to a second lockdown, in October 2020. In early December, restrictions were eased once more only to be reintroduced in January amid a third wave of the virus. The third lockdown began to be eased in April 2021. Each lockdown resulted in an uptick in PUP and wage subsidy claimants. Currently, this lockdown is being slowly lifted and there is an expectation that, with the pace of the vaccine rollout, no further strict lockdowns will be needed. It is natural, therefore, that attention will now turn to the withdrawal of the PUP and EWSS payments.

The unemployment rate in Ireland between 2005 and the present is shown in Figure 2.1. The black lines depict the overall unemployment rate of those aged 15-74 while the blue lines show the youth (15-24) unemployment rate. The continuous lines show the standard monthly unemployment rate while the dashed lines show the COVID-19 adjusted monthly unemployment rate. This latter measure includes all those in receipt of the PUP. The Central Statistics Office (CSO) points out that not everyone in receipt of PUP would be eligible for a pre-existing unemployment payment. There are a number of reasons why someone losing their job as a result of COVID-19 would not be entitled to a pre-existing payment. An individual may not qualify for the non-means-tested JSB due to an inadequate PRSI contribution history. Younger workers are particularly likely to fall into this category. They are less likely to qualify for standard unemployment insurance schemes due to short and unstable employment records (OECD, 2021). The non-contribution-based JSA, which is means-tested, acts as a second safety net but an individual may have no entitlement if their means are too high - for example, if their spouse or partner is in employment. Those aged under 25 and living with their parent(s) have their parental income taken into account in the means test for JSA. ${ }^{3}$ Another group who would not be eligible for a pre-existing payment such as JSB or JSA are full-time students as they are excluded from these schemes based on their education status. Full-time students seeking employment would, therefore, traditionally not be included in the numbers unemployed. It is estimated that, in

This is based on the 'Benefit and Privilege' enjoyed by that person by virtue of residing with a parent/stepparent. Some exemptions apply, such as if the individual is married/cohabiting with a partner or has returned to the parental home having lived independently for a significant length of time. 
April 2021, at least 34 per cent of PUP recipients aged under 25 (or 8 per cent of total PUP recipients) were registered as full-time students (CSO, 2021) and therefore ineligible for JSA or JSB.

The unemployment rate rose from 5 per cent in February 2020 to 30.5 per cent in April 2020, using the COVID-19 adjusted monthly unemployment rate. ${ }^{4}$ It has fluctuated as restrictions eased and tightened but still remains well above pre-pandemic levels. What is evident from Figure 2.1 is that the youth unemployment rate is much higher than that of the total population - rising to nearly 64 per cent in April 2020 and remaining close to 60 per cent in recent months. Looking back over time, we see that the youth unemployment rate has tended to be consistently above the overall rate, including even in the early 2000 s. As has been noted in Roantree et al. (2021), young people were also more affected by the Great Recession. This is evidenced by a larger pre-pandemic gap between youth unemployment rates and the overall unemployment rate.

\section{FIGURE 2.1 UNEMPLOYMENT RATE, STANDARD AND COVID-19 ADJUSTED}

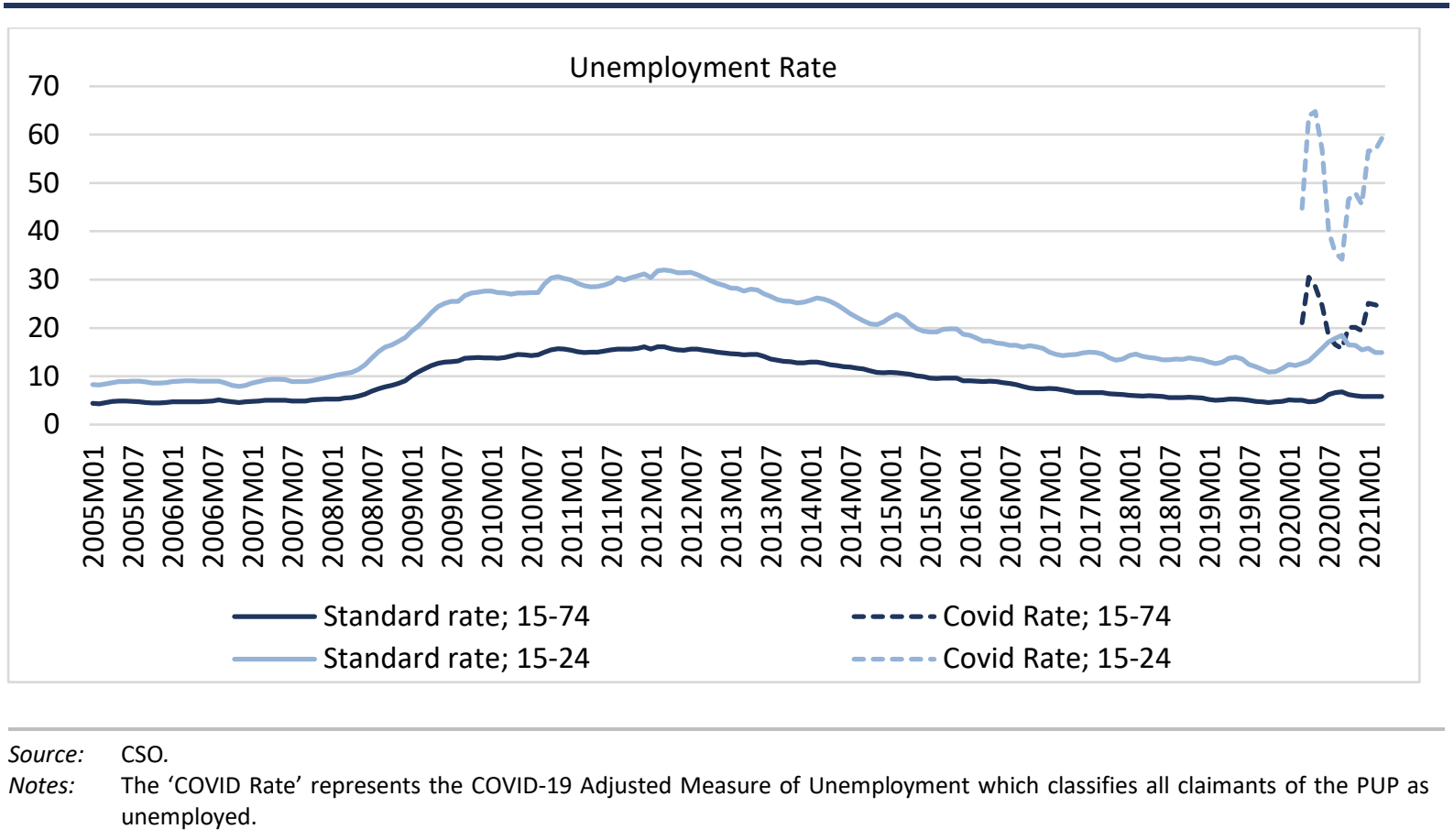

Figure 2.2 shows the number of PUP recipients since March 2020, with recipient numbers peaking in April 2020. Recipient numbers fell during the summer of 2020, rising again with the latest lockdown. Numbers have continued to fall in recent months. Figure 2.3 shows the trend in TWSS and EWSS recipients since March 2020. Figures disaggregated by age are available for the TWSS, but not since the transition to the EWSS. The number of employees receiving a wage subsidy peaked at around 450,000 between April and July 2020. There was a decrease in recipient numbers to around 350,000 between then and the transition to the EWSS. The

$4 \quad$ i.e. including all claimants of the PUP as being unemployed. 
latest available figures show that around 300,000 employees were receiving the

EWSS in April 2021.

FIGURE 2.2 NUMBER OF PUP RECIPIENTS BY AGE

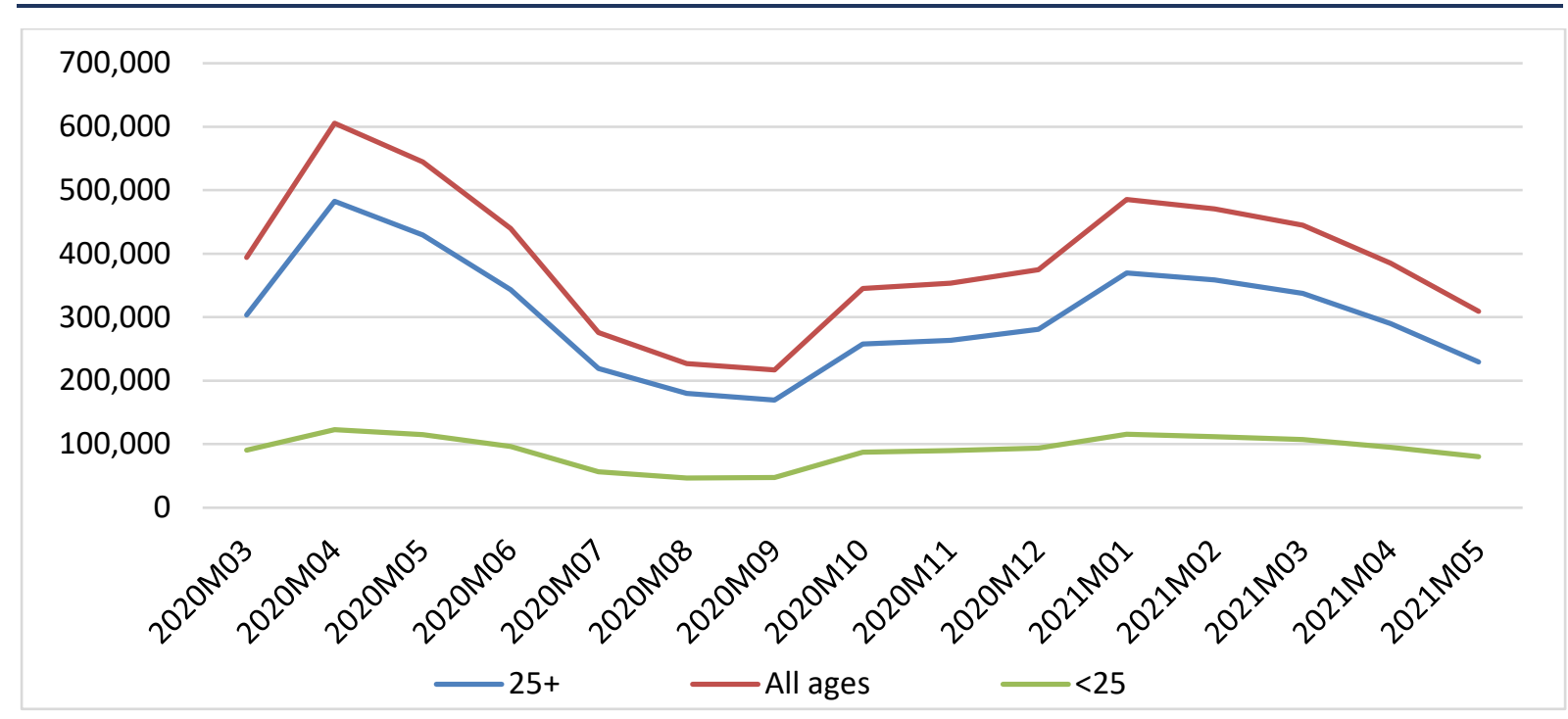

Source: $\quad$ CSO, LRM20 - Number of Persons on the Live Register, in receipt of the PUP and supported by the TWSS or EWSS.

\section{FIGURE 2.3 NUMBER OF TWSS/EWSS RECIPIENTS BY AGE}

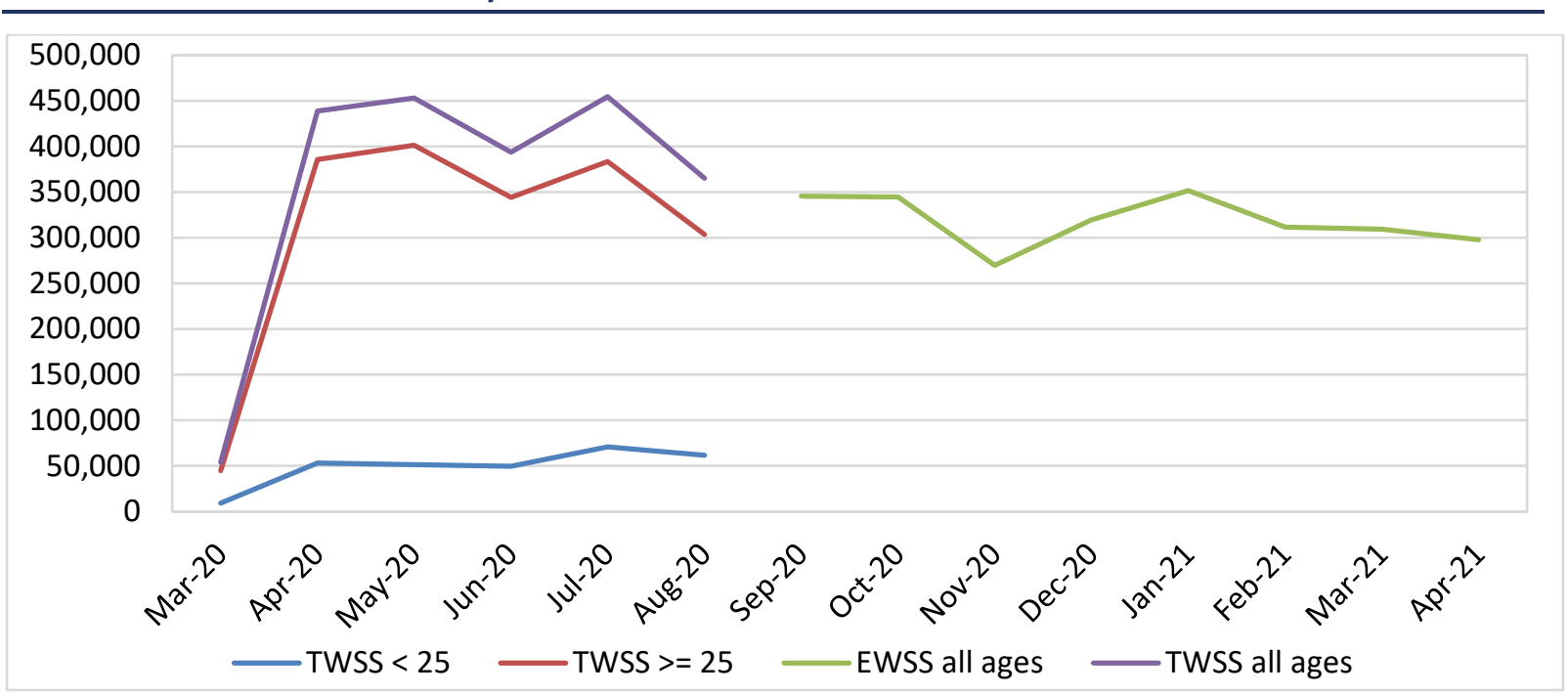

Source: TWSS statistics from Persons on the Live Register and Persons in receipt of the Pandemic Unemployment Payment and the Temporary COVID-19 Wage Subsidy Scheme. EWSS statistics from https://www.revenue.ie/en/corporate/information-aboutrevenue/statistics/number-of-taxpayers-and-returns/covid-19-support-schemes-statistics.aspx.

Overall, the number of workers whose income was being supported by the State at the peak of the crisis was substantial. In April 2020, an estimated 1.18 million individuals, nearly one quarter of the Irish population or half of all workers, were in receipt of either the PUP or a wage subsidy, or were on the Live Register. ${ }^{5}$

The Live Register captures those who are fully unemployed and in receipt of unemployment supports such as JSB or JSA. It also captures those who are 'partially' unemployed, i.e. those who work up to three days a week but are entitled to JSA or JSB. 


\section{SECTION 3}

\section{The effect of pandemic-related unemployment}

This section examines the effect of pandemic-related unemployment and income supports on income distribution. A rapid development and deployment of appropriate methodologies to examine the effect of the pandemic and policy supports on income distribution began as early as April 2020, both in Ireland and internationally. A key problem in carrying out research looking at the effect of the pandemic on incomes, and other aspects, is that survey data used for such analysis always come with a time-lag. Even administrative data can take time to collate and publish. For example, the main official data source on employment and unemployment in Ireland - the Labour Force Survey (LFS) - is available with a sixmonth time-lag. At the time of writing, June 2021, the latest LFS data available are for Quarter 4 of 2020. Likewise, the main data source on income and living conditions - the CSO's Survey of Income and Living Conditions (SILC) - is currently only available for 2019, well in advance of the COVID-19 pandemic. Microsimulation models are used in Ireland and across nearly all Western countries to respond to such data lags. These models adjust data to be representative of the current year, thus allowing for more up-to-date analysis. Adjusting the data is usually relatively straightforward; it can include, for example, increasing incomes in line with average wage inflation between the data-collection year and the current year. The key challenge was, and remains, the transformation of survey data collected prior to the pandemic into a dataset representative of the current population, given the widespread impact of COVID-19 on employment and incomes. ${ }^{6}$ Nowcasting and reweighting methodologies, which align observed employment and income from historical survey sources with more current administrative information, have been very effectively used by, among others, O'Donoghue et al. (2020); Beirne et al. (2020); Almeida et al. (2020).

Our analysis uses SWITCH, the ESRI's tax benefit model, which employs the harmonised method developed at EU level for nowcasting pandemic-related job losses (Cantó Sánchez, et al., 2021). SWITCH is linked to data from the $2017^{7}$ SILC, the primary source of information on household incomes, collected annually by the CSO. The scale, depth and diversity of this survey allows it to provide an overall representative picture of the impact of the policy changes on Irish households, which cannot be gained from selected example cases.

Migration may also affect how the current income distribution compares to that recorded in surveys prior to the pandemic. This is not explicitly accounted for in our methodology.

2017 data were the most recent year of data operational in SWITCH, the ESRI microsimulation model. While more recent SILC data are available, it is time-intensive to prepare the data for use in the model so it is usually updated biennially. The model is currently being updated to 2019 data, the latest available. 
We first adjust the 2017 data to be representative of the current population in terms of unemployment rates. A proportion of workers in each industry are assumed to have either lost their job or to have been put on the EWSS. The number of individuals to either lose their job or receive the EWSS is calibrated from publicly available data from the CSO on the number of people in receipt of the PUP and the TWSS. Both calibrations are done using end-August 2020 figures, the latest available data, which account for the industry and age breakdown of recipients of either scheme. ${ }^{8}$ The total number of workers simulated to be displaced (either claiming the PUP or supported by the EWSS) amounts to 523,000 - compared to a current total of 584,000 at the time of writing. ${ }^{9}$ While the current number of displaced workers is higher than our simulations, it is expected to come down significantly during the month of June as hospitality continues to reopen. The data are also adjusted to take account of income growth between 2017 and 2021. ${ }^{10}$

We then use SWITCH to calculate households' social welfare entitlements, tax liabilities and net incomes, under our baseline policy. This indexes the policy rules in place in February 2020 by forecast inflation of 0.2 per cent ${ }^{11}$ between 2020 and 2021 to provide a benchmark that holds welfare payments, tax credits and thresholds constant in real terms. Comparing this scenario (COVID-19: no policy response) to one in which there is no unemployment shock (Pre-COVID) shows in net terms the effect of pandemic-related unemployment on incomes, accounting for the offsetting effect of lower tax liabilities and higher social welfare entitlements (so-called 'automatic stabilisers').

In the second stage, we incorporate the PUP and the EWSS. This scenario, COVID-19: PUP + EWSS, is compared to the COVID-19: no policy response scenario to show the cost and distributional effect of these supports. A key assumption in this stage of the analysis is the number of jobs supported by the EWSS that would have been lost in the absence of this policy measure. Our central assumption is that 50 per cent of jobs supported by the EWSS would have been lost in the absence of this policy measure. Alternative estimates based on 25 per cent and 75 per cent job losses are also reported. by the EWSS.

10 For example, employment income is uprated by 1.12 using data from the CSO and the ESRI Quarterly Economic Commentary, and self-employment income is uprated by 1.04 using both data from the CSO and national income forecasts in the ESRI Quarterly Economic Commentary. 


\subsection{DISTRIBUTIONAL EFFECT}

Figure 3.1 shows how the pandemic has affected the distribution of tax unit income, adjusted for family size, with the population divided into five equally sized groups (quintiles) ordered from lowest- to highest-income, left to right. In the absence of the PUP and EWSS, we estimate that pandemic-related unemployment would have decreased household income by 7 per cent. This is substantially below the figure estimated by Cahill and Lydon (2021) who examined the impact of the pandemic on the incomes of Irish households and how incomes would have been affected were it not for the COVID-19 income supports. The authors found that gross household income would have fallen by a much larger 20 per cent in Q2 of 2020 in the absence of PUP and wage subsidies. Some of this difference is due to the fact that they examine a period when COVID-related restrictions were tighter, hence job and income losses were larger. Another key reason for this difference is the authors' assumption that those losing their job as a result of COVID-19 would not have received any other benefits if the PUP and wage subsidies had not been introduced. Using microsimulation, Doorley et al. (2020) highlighted the importance of the existing tax-benefit system, which would have substantially cushioned pandemic-related income losses even if the PUP had not been introduced. We estimate that, of those in receipt of PUP, 92 per cent would have been entitled to a pre-existing benefit, such as JSB or JSA; the assumption in Cahill and Lydon (2021) that those in receipt of the PUP would not have received other pre-existing benefits will significantly overestimate COVID-related income losses. Accounting for these automatic stabilisers, income losses in the absence of the PUP and EWSS are estimated at a more modest 7 per cent in our central scenario. Under the assumption that 25 per cent of jobs supported by the EWSS would be lost in its absence, this figure is 6 per cent, rising to 8 per cent if we assume 75 per cent of jobs supported by the EWSS would be lost in its absence.

This average 7 per cent loss is not equally distributed. Households in the lowest quintile group saw little change to their income as (1) they are less likely to contain a worker and to be exposed to the unemployment shock and (2) the existing taxbenefit system (e.g. JSB, JSA, etc) does a good job of sheltering the incomes of those in this income quintile from job losses. Losses increase further up the income distribution; those in the upper half of the income distribution experience the largest income loss - 7-9 per cent. 
FIGURE 3.1 DISTRIBUTIONAL EFFECT OF EMPLOYMENT LOSSES WITH AND WITHOUT COVID-19 POLICIES

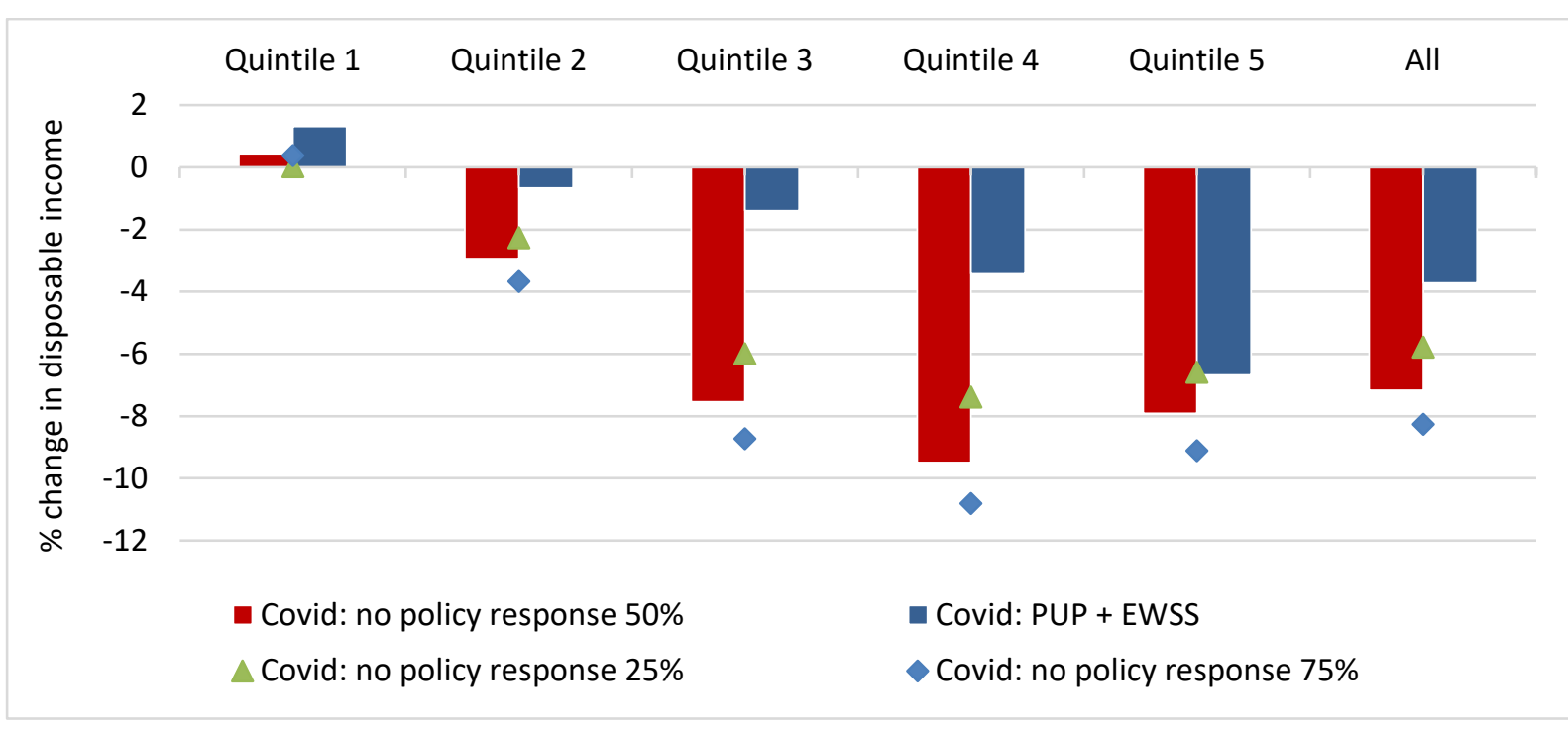

Source: Authors' calculations using SWITCH run on 2017 Survey of Income and Living Conditions data, uprated to 2021 income levels. Notes: Quintiles are based on equivalised household income, using CSO national equivalence scales.

The analysis is presented at a family unit level, grouping together couples and their children in education or under the age of 18. Multiple families can live in the same household.

COVID: no policy response 50 per cent ( 25 per cent or 75 per cent) assumes that, in the absence of the EWSS, 50 per cent ( 25 per cent or 75 per cent) of the jobs it supports would be lost.

COVID: PUP + EWSS assumes that both PUP and EWSS are in place for eligible recipients.

All four scenarios are compared to the situation where there is no pandemic-related job loss (Pre-COVID scenario).

The initial policy response to the pandemic (PUP and EWSS) ${ }^{12}$ decreases the average family income loss from 7 per cent to 3 per cent under the assumption that 50 per cent of jobs supported by the EWSS would have been lost in its absence. ${ }^{13}$ Families in the lowest income quintile actually experienced small income gains compared to the Pre-COVID scenario as a result of the more generous rate of PUP. Losses are small in quintiles three and four. Only quintile 5 still experiences large average income losses - of 6 per cent - compared to the Pre-COVID scenario. O'Donoghue et al. (2020) also report this progressive pattern of pandemic-related income supports, with low-income households gaining from income supports, compared to the pre-pandemic situation. The distribution of losses across income quintiles is very similar when applying the 25 per cent and 75 per cent job loss scenarios.

Doorley et al. (2020) show that the groups most affected by pandemic-related job loss and who stand to lose the most once the PUP and EWSS are withdrawn include young adults and those working in the hospitality and arts sectors. Beirne et al.

12 It is not possible to identify those who would have received the Enhanced Illness Benefit. However, the effect of the scheme is likely small, given that the maximum benefit duration is two weeks.

13 It is difficult to estimate how many EWSS-supported jobs would have been lost in the absence of the scheme. Our central scenario assumes that this figure is 50 per cent. Results from two alternative assumptions are also displayed in Figure 3.1; COVID: no policy response 25 per cent ( 75 per cent) assumes that 25 per cent ( 75 per cent) of EWSS recipients would have lost their job in the absence of the subsidy. 
(2020) showed that the introduction of the PUP and EWSS resulted in significantly fewer families experiencing large income losses, defined as more than 20 per cent. Table 3.1 provides a profile of those aged 18-66 who, in the COVID: no policy response 50 per cent scenario - i.e. if PUP and EWSS were not in place - (i) lose disposable income and (ii) lose more than 20 per cent of disposable income.

In the absence of the PUP and EWSS, Table 3.1 indicates that 16 per cent of the adult population would have lost disposable income and, of this group, 74 per cent would have lost more than 20 per cent of disposable income. Looking at particular demographic categories indicates which groups stand to lose most if the PUP and EWSS are withdrawn before ample labour-market opportunities are available.

TABLE 3.1

A PROFILE OF WORKING-AGE ADULTS WHO LOSE DISPOSABLE INCOME AND LOSE MORE THAN 20 PER CENT OF DISPOSABLE INCOME AS A RESULT OF PANDEMICRELATED JOB LOSS IN THE ABSENCE OF THE PUP AND EWSS.

\begin{tabular}{|c|c|c|c|}
\hline & $\begin{array}{c}\text { Proportion who } \\
\text { lose income \% }\end{array}$ & $\begin{array}{c}\text { Proportion who lose } \\
>20 \% \text { income } \%\end{array}$ & $\begin{array}{c}\text { Group size as a proportion } \\
\text { of total population } \%\end{array}$ \\
\hline Total & 16 & 75 & 100 \\
\hline \multicolumn{4}{|l|}{ By age group } \\
\hline $18-24$ & 19 & 91 & 14 \\
\hline $25-34$ & 20 & 72 & 19 \\
\hline $35-44$ & 18 & 76 & 22 \\
\hline $45-54$ & 14 & 73 & 23 \\
\hline $55-66$ & 11 & 63 & 22 \\
\hline \multicolumn{4}{|l|}{ By gender } \\
\hline Men & 15 & 76 & 51 \\
\hline Women & 17 & 74 & 49 \\
\hline \multicolumn{4}{|l|}{ By family type } \\
\hline Working age single without children & 18 & 87 & 27 \\
\hline Working age lone parent & 10 & 25 & 7 \\
\hline Working age couple without children & 16 & 72 & 23 \\
\hline Working age couple with children & 17 & 72 & 41 \\
\hline \multicolumn{4}{|l|}{ By education status } \\
\hline In education & 13 & 78 & 14 \\
\hline \multicolumn{4}{|l|}{ By income quintile } \\
\hline Q1 & 7 & 4 & 21 \\
\hline Q2 & 18 & 13 & 16 \\
\hline Q3 & 26 & 20 & 20 \\
\hline Q4 & 19 & 15 & 21 \\
\hline Q5 & 11 & 8 & 23 \\
\hline
\end{tabular}

Source: Authors' calculations using SWITCH run on 2017 Survey of Income and Living Conditions data, uprated to 2021 income levels.

Notes: $\quad$ Sample is aged 18-66. It is assumed that 50 per cent of jobs supported by the EWSS are lost in the absence of this policy. While income changes are reported at the individual level, income quintiles are defined based on equivalised disposable income at the tax-unit level. Family types are also defined at the tax-unit level. A tax unit represents a married couple or single person, together with all children aged less than 18 , and children aged 18 or older who are in full-time education. Equivalisation is done using the CSO's equivalence scale. 
The proportion of losers is higher (19-20 per cent) for those aged 18-44 than for those aged 45-66 (11-14 per cent). Almost all (91 per cent) of 18-24-year-olds who lose income lose more than 20 per cent of disposable income. This figure is lower (64-74 per cent) for other age groups. This is likely to be linked to lower benefit entitlement for young adults compared to other age groups. As mentioned in Section 2, young people often do not qualify for contribution-based schemes such as JSB due to minimum contribution rules, and students cannot claim JSB or JSA. In addition, the JSA rate for those under 25 who live with their parents is 45 per cent lower than for those 25 and over.

By gender, we find that women are slightly more likely than men to lose disposable income in the absence of the PUP and EWSS. Among those who lose income, however, the proportion of men and women losing more than 20 per cent of disposable income is similar. This is in line with the findings of Doorley et al. (2021) and Doorley et al. (2020) that women and men have, so far, been fairly similarly affected by job and income losses due to the COVID-19 pandemic in Ireland.

Among family types, lone parents are the group least affected by income loss in the absence of the PUP and EWSS. This finding is explained by their lower labourmarket attachment - which makes them less exposed to pandemic-related job loss compared to other demographic groups - and their eligibility for the One-Parent Family Payment if they have a child under seven.

A total of 13 per cent of those in education are affected by income losses and, within this group, 82 per cent lose more than 20 per cent of their disposable income. This is likely to be explained by the fact that students are not eligible for standard jobseekers' supports such as JSA and JSB.

Lastly, losses are unevenly distributed by income quintile. ${ }^{14}$ Fewer working-age adults in the lowest and the highest income quintiles experience income losses in the absence of the PUP and EWSS. Of those who do experience income losses in these income quintiles, fewer experience large (greater than 20 per cent of disposable income) losses. These findings are explained by relatively generous automatic stabilisers for low-income households (i.e. jobseekers' supports) and lower job loss rates among high-income households. By contrast, quintiles two, three and four contain relatively more working-age adults who experience both income losses and large income losses. 


\subsection{WORK INCENTIVES}

The availability of the PUP changes financial work incentives. The financial incentive to work is irrelevant if there is no work available or if individuals are prohibited from working due to public health restrictions. However, it is important to consider what effect the PUP may have on financial incentives to work as the economy begins to reopen and the labour market recovers.

Two commonly used measures of the financial incentive to be in paid work are the replacement rate (RR) - which gives an individual's out-of-work income as a percentage of their in-work income - and the participation tax rate (PTR), which gives the proportion of earnings that are taken away in tax or lower benefit entitlements when an individual starts work. For both measures, disposable income is measured after benefits have been added and taxes deducted. Low (high) numbers indicate that the financial incentive to work is strong (weak). Broadly speaking, the RR measures the absolute strength of financial incentives to work whereas the PTR measures the effect of the tax and benefit system on work incentives. The RR also reflects the level of income support an individual faces when losing their job. Therefore, while a high RR will reflect lower financial incentives to work it will also reflect a higher level of income support for those losing their job. This issue is discussed more in Section 4.1.

Figure 3.2 plots the estimated cumulative distribution of these measures for those who we simulate to lose their job - i.e. the proportion of the population (read from the vertical axis) facing an RR or PTR less than that shown on the horizontal axis. ${ }^{15}$ The red line indicates a RR or PTR of 100 or more - i.e. no financial incentive to work. The left-hand side panel shows that virtually all of those losing their job as a result of COVID-19 would have had an RR below 100 per cent (i.e. receive less in benefits than in employment) under the tax and welfare system in operation prior to the pandemic, before the PUP and EWSS were introduced. More than 90 per cent of those simulated to be unemployed due to the pandemic would have had an RR below 75 per cent in this system. The vast majority have a RR between 25 per cent and 50 per cent, which indicates a strong financial incentive to work, but also weaker income support in the event of losing a job as the welfare system would only replace between one quarter and half of employment earnings. 


\section{FIGURE 3.2 ESTIMATED REPLACEMENT RATE (LEFT) AND PARTICIPATION TAX RATE (RIGHT) OF THE NEWLY UNEMPLOYED}
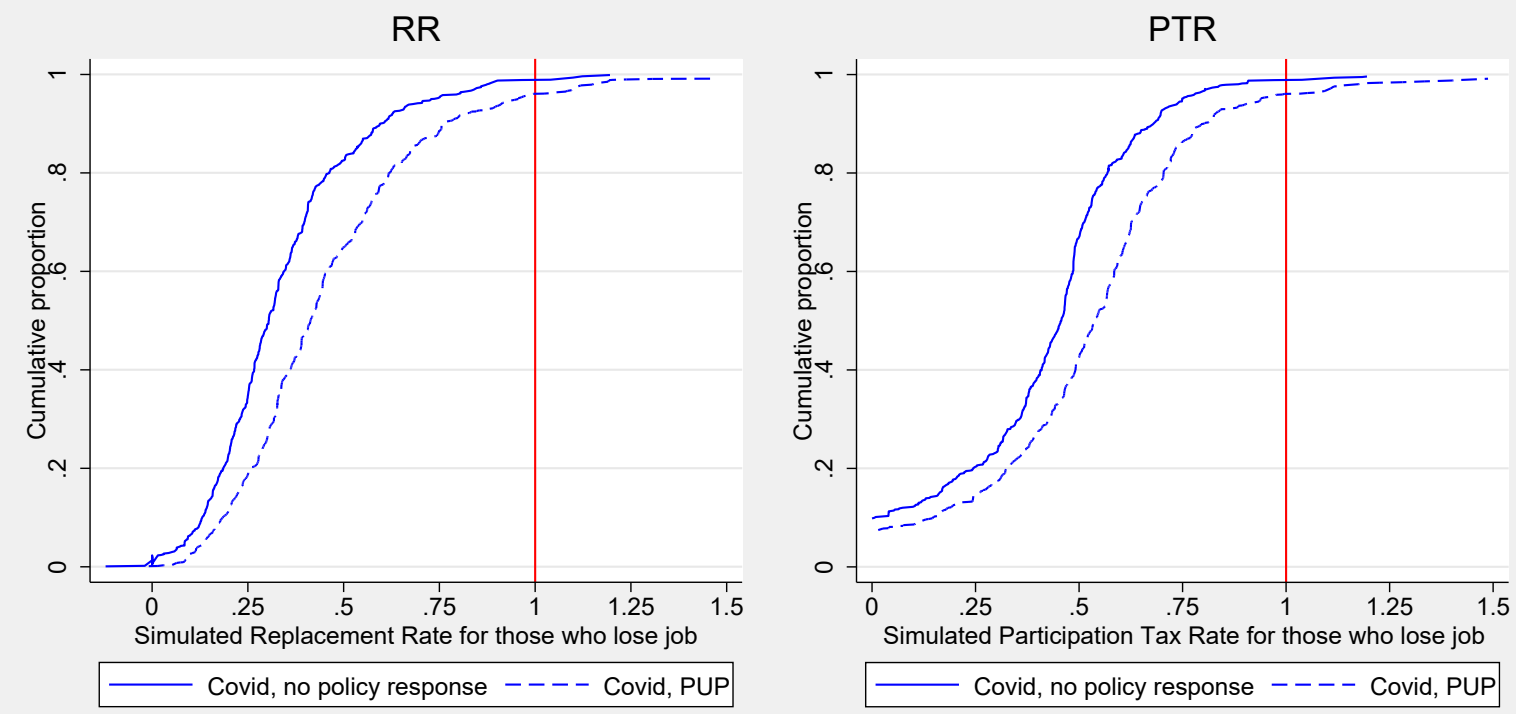

Source: Own calculations using SWITCH v3.1.

Accounting for the PUP in these simulations, financial incentives to work weaken slightly. This is a reflection of the fact that the PUP has a tighter link to previous earnings, with higher rates compared to the personal rates of JSA and JSB - so that the PUP replaces more of the employment income lost. Approximately 5 per cent of individuals have an RR greater than 100 per cent once the PUP is introduced i.e. no financial incentive to work. Close to 15 per cent of the newly unemployed have a relatively high $\mathrm{RR}$, greater than 75 per cent. It is also worth bearing in mind that RRs and PTRs are calculated based on net income after taxes and other charges such as PRSI. As discussed in O'Donoghue et al. (2021), certain living costs may have reduced during the pandemic, such as commuting and childcare costs, as a result of the restrictions in place.

The right-hand side panel shows that PTRs tell the same story. While fewer than 5 per cent of individuals had a PTR in excess of 75 per cent under the original tax and welfare system, almost 15 per cent do when accounting for the PUP. This suggests that financial work incentives are substantially weaker for many workers with the PUP in place, as measured by either the RR or PTR, but also that the PUP supported income losses to a greater extent than the pre-existing unemployment supports would have done.

It is important to bear in mind that not all those with weak financial incentives to work will opt for unemployment or inactivity. As shown in Figure 3.1, even before the introduction of the PUP, those in the bottom income quintile would have seen a small average increase in income as a result of the employment shock. This is 
because some of those in the lowest income group, likely with relatively low pay, would have had a higher disposable income if they were to rely on the pre-existing unemployment supports such as JSA and JSB. This finding ties in with previous ESRI research (Savage, et al., 2015) that showed that, of those that would have had a higher disposable income out of work than in work (an RR of 100 per cent or more), 90 per cent were actually in employment. This can arise for a variety of reasons. Individuals may face low financial work incentives at the start of their working life but expect an increase in the future and thus stay in employment. They may also derive personal satisfaction from working and associate unemployment or inactivity with social stigma. A key takeaway is that financial incentives are not the only types of work incentives and that a substantial number of people who would be better off financially not working choose to do so anyway. 



\section{SECTION 4}

\section{Challenges for the welfare system}

The results in Section 3 highlight the fact that certain groups - young adults, workers in middle-income households and students - would face hardship if the PUP and/or EWSS were to be withdrawn entirely before sufficient employment opportunities become available. On the other hand, concerns around a lack of financial incentives to work triggered by the COVID-19-related income support schemes have been raised. As shown in Section 3, while the PUP remains in place, financial incentives to work are slightly weaker for the newly unemployed. Measures of financial work incentives are not on their own sufficient to infer how individuals might act in the labour market. Also of importance is how responsive or elastic - people are to these incentives. Many of the jobs which were lost over the last year were lost because they could not be carried out at home or safely in the workplace. As a result, it is possible that workers will require a higher financial incentive to return to such jobs as the economy reopens, to compensate for the greater risk of contracting COVID-19 or the fact that fixed costs of work (such as travel time and cost) are relatively greater than for other sections of the population. In addition, unemployment is anticipated to remain elevated in 2022 (McQuinn, et al., 2021). For those who do return to employment, firms in some sectors may struggle to return all workers back to pre-COVID-19 work hours or pay levels. Earnings may therefore be depressed in certain sectors as they recover.

The cost of these schemes will also be a factor in decisions around their withdrawal. Doorley et al. (2020) estimate that the cost of the PUP and EWSS pandemic-related supports is around $€ 200$ million per month per 100,000 displaced workers. More than half of this cost would be incurred anyway through automatic stabilisers. Any future changes to the generosity of the welfare system will, of course, present a separate cost to the Exchequer. Research in the UK (BSA, 2020) has shown that public support for welfare benefits just before the COVID-19 crisis was already at the highest level seen in 20 years. While policy changes that increase the generosity or coverage of safety nets will come at a cost, the support for associated tax increases to fund some of the changes is likely to be higher than it would have been before the onset of the pandemic. ${ }^{16}$ The OECD (2021) also finds stronger demand for government income support and a willingness to pay higher taxes to fund such supports. It is therefore possible that the pandemic will affect the way citizens feel about the welfare system and the government role in providing a safety net for its citizens. The scale of income support policies that have

16 It is worth noting that the funding of the COVID-related supports put in place by government was possible due to borrowing at low interest rates, facilitated by the European Central Bank. Future reforms will likely need to be funded from tax increases. Roantree and Kakoulidou (2021) provide an overview of options for raising tax revenue in Ireland should the government choose to do so. 
been introduced in the last year, and the speed of their introduction, is unprecedented in living memory. Tax and welfare policy changes usually happen once a year in the annual Budget. The Government has reacted swiftly, and often, in introducing and reforming income supports in reaction to the evolving pandemic. Even during the Great Recession there was only one year in which a 'Supplementary Budget' was introduced (2009) with additional social welfare changes. Therefore, the current crisis may provide an opportune time for system reforms. In this section, we examine some of the issues that the COVID-19 crisis has highlighted in the welfare system and some potential policy changes to tackle these issues.

\subsection{JOBSEEKERS' SUPPORTS}

\section{Benefit level and duration}

The PUP has a higher rate of payment ${ }^{17}$ and stronger earnings link than the preexisting JSB and JSA, as shown in Table A.1. For example, a single person earning $€ 310$ per week before entering unemployment would receive $€ 300$ under the PUP but only $€ 203$ in JSB. A higher-earning single person who earned $€ 500$ per week before their job loss would receive the maximum PUP rate of $€ 350$ but still only $€ 203$ per week in JSB ${ }^{18}$ As discussed in O'Donoghue et al. (2021), it was recognised that the current rates of JSA or JSB would not be sufficient and that it might be difficult for families to adjust their costs of living in the shorter term.

Many European and OECD countries have stronger links between pre-employment earnings and initial unemployment benefits such as JSB, with unemployment benefits replacing more of the pre-job loss employment income, at least in the shorter term. This helps families to cope with their pre-job loss non-discretionary living costs such as housing, ${ }^{19}$ providing financial support while an individual searches for a job or tries to reduce living costs to a more affordable level.

In Ireland those with sufficient PRSI contributions can receive JSB for nine months before moving to JSA. The maximum rates of the two payments do not differ, however. A single, childless person earning the average wage has a net replacement rate (RR) of 29 per cent (i.e. 29 per cent of their earnings are replaced by unemployment benefits) in Ireland compared to the OECD average of 55 per cent, excluding housing benefits. Including housing benefits, this RR rises to 45 per cent, still significantly below the OECD average of 58 per cent. ${ }^{20}$ This raises

17 This is compared to the personal rate of JSB or JSA. However, JSA and JSB can include increases for qualified adults and children.

18 The amount received in JSA may ultimately be lower as JSB is not means-tested, while JSA is.

19 A housing benefit known as Rent Supplement exists for those who lose their job and are in rented accommodation. The housing benefit support for those in owner-occupied, mortgaged accommodation - Mortgage Interest Supplement - was discontinued in 2014, with no new applications allowed since that date. 
questions about whether policymakers should be thinking in the medium to long term about strengthening the link between JSB and prior earnings. Recent comments by An Tánaiste suggested that such a change is likely in the future as the PUP winds down. ${ }^{21}$

A significant cost-cutting change to unemployment payments, enacted after the Great Recession, will affect the unemployed once the PUP is withdrawn. The maximum duration of JSB was reduced from 12 to nine months. As the PUP awards no increases for 'qualified' adults or children, some who lost their job during the pandemic were financially better off on JSB, which pays a maximum rate of $€ 203$ per week to the claimant, with top-ups of $€ 134.70$ for a qualified adult such as a spouse along with increases for children ranging from $€ 38$ to $€ 45$ weekly per child. As the pandemic continues, individuals who were initially better off on and awarded JSB are likely to have exhausted their nine months' entitlement and will be moved either to JSA or PUP, depending on which is highest for their situation. ${ }^{22}$ In either case, this will result in a lower payment than JSB. Given the fact that 15 months have passed since the first lockdown in Ireland, it is likely that many families who were initially in receipt of JSB have already experienced this reduction in income. Across the OECD, the duration of entitlement to unemployment insurance benefits varies from three months in Hungary to three years in Denmark. Ireland is one of ten countries that have a maximum duration of nine months, compared to 21 countries with longer maximum durations. ${ }^{23}$

This reduced duration of JSB since 2013 will also amplify inequities between those who lost their jobs just prior to the pandemic and those who lost their jobs after the introduction of the PUP. The former group, if still unemployed, will have exhausted their JSB entitlement (assuming they qualified initially) after nine months and will have moved to the means-tested JSA payment, while those who lost their job after March 2020 can move back onto the non-means-tested PUP payment once they have exhausted their JSB eligibility.

\section{Youth rate}

A second substantial change made in the wake of the Great Recession was to the 'youth' rate of JSA. Up to 2009 , those under $25^{24}$ received the same JSA rate as those over 25. The Supplementary Budget of 2009 cut the rate of JSA for those aged 18 and 19 by over 50 per cent; the stated aim was to ensure that young people were better off in education, employment or training than claiming benefits. These cuts were extended over the following years to higher ages, with the age distinction rising to 25 by Budget 2011. While the under- 25 rate has increased in 
recent years, ${ }^{25}$ it is still 45 per cent lower than the over- 25 rate. In the wake of the Great Recession, this policy change also had a financial motivation, as youth unemployment rates were high. Cuts to benefits can strengthen the financial incentive to work as they reduce the gap between in-work and out-of-work income. However, there may be limited employment effects if demand for labour is low. Doris et al. (2020) examined the initial JSA rate cut for those under 21 and found that this policy change reduced unemployment duration for 18-19-year-olds but not for those aged 20 and over, suggesting that the policy change had limited beneficial long-run labour-market effects.

If the under-25 rate for JSA is deemed to be too low - as was the case with the PUP, where no age distinction was made, one possible change would be to restore the under- 25 rate to that of those aged 25 and over. Using SWITCH, we estimate the cost and distributional effect of restoring the under-25 JSA payment to the over-25 rate. Figure 4.1 compares the distribution of income changes for the two scenarios presented in Section 3 (COVID: no policy response and COVID: PUP + EWSS) to a scenario with COVID-related job losses and, instead of the PUP and EWSS, a reform to JSA which equalises the payments to those under and over 25 years of age. The JSA reform, which we estimate to cost €159-168 million per annum, ${ }^{26}$ primarily affects the bottom income quintile, where it increases income by 4 per cent on average, compared to 0 per cent in the COVID: no policy response scenario and almost 2 per cent in the COVID: PUP + EWSS scenario. There is no effect of the JSA reform visible in other income quintiles.

25 The current personal rates of JSA are $€ 112.70$ for those aged $18-24$ and $€ 203$ for those aged 25 and above. Some 18-24-year-olds can receive the higher rate - for example, those living independently and in receipt of a housing benefit such as the Housing Assistance Payment, or those with a child dependant.

26 The costing of $€ 159$ million per annum assumes no pandemic-related unemployment while the costing of $€ 168$ million assumes 523,000 workers displaced due to the pandemic. Comparing this to the total $€ 2$ billion expenditure on JSA and JSB in 2019, prior to the pandemic, this would equate to around 8 per cent of this total expenditure on unemployment supports but should reduce as youth unemployment falls. 
FIGURE 4.1 DISTRIBUTIONAL EFFECT OF EMPLOYMENT LOSSES WITH AND WITHOUT COVID-19 POLICIES AND JSA REFORM

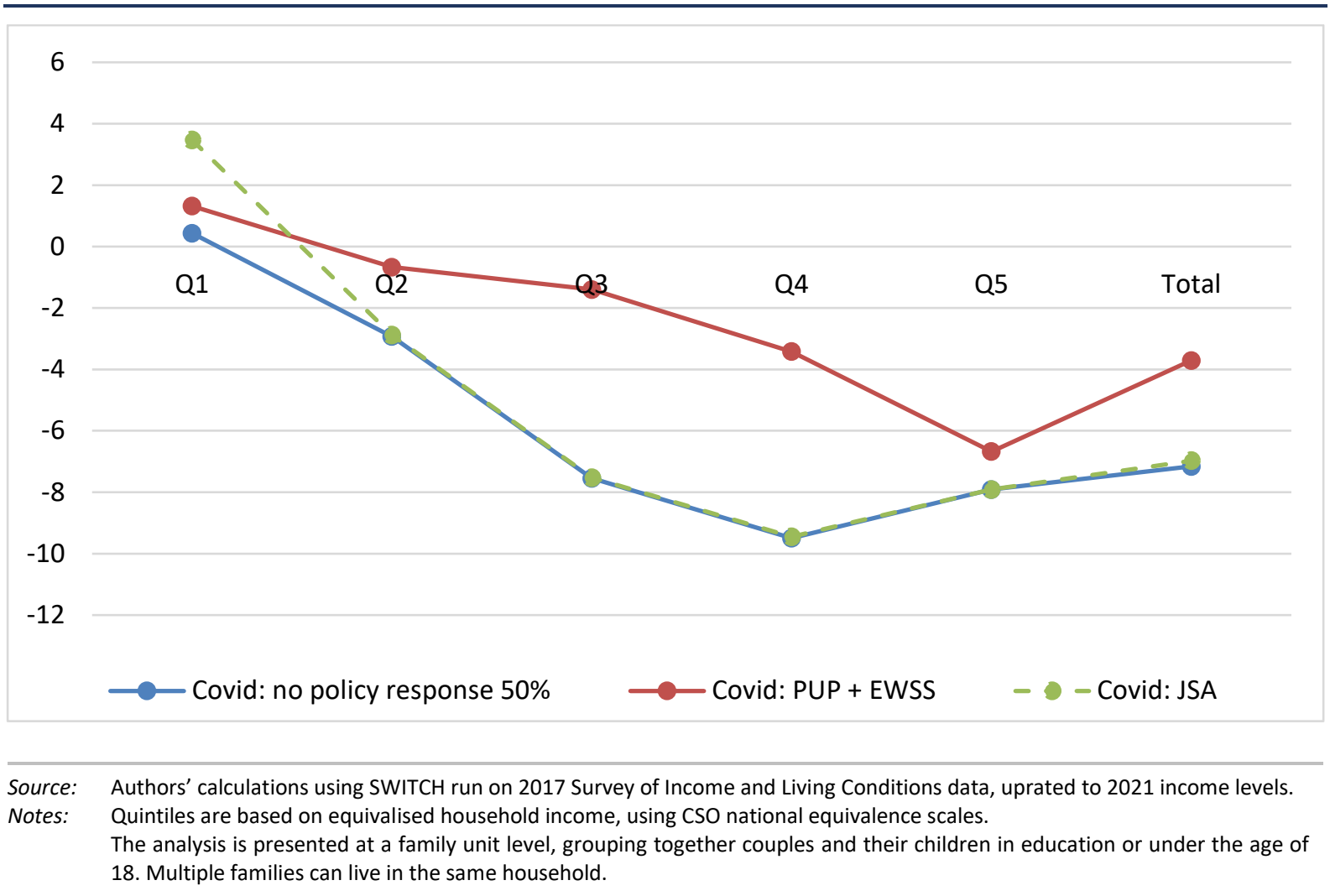

An alternative means of improving incentives to work is to allow recipients of social welfare payments such as the PUP to keep (part of) their welfare payment when they take up a job and to withdraw the benefit as earned income increases, and not as days in work increase. Bargain and Doorley (2017) found that such a reform to the minimum income in France, which saw recipients keep part of their benefit when taking up work, had a large positive effect on incentives to work, especially for young adults.

Given the substantial impact of the pandemic on the employment and income of young adults and the likelihood that youth employment will recover slower than that of other age groups, reform to the youth rate of JSA could help to bolster the income of this group.

\section{PUP and work incentives}

Entitlement to JSB and JSA payments continues (at a reduced rate) if an individual is unemployed for at least four out of seven consecutive days. Despite the issues surrounding this rule, discussed further in Section 4.2, it does improve the financial incentive to work for those in receipt of one of these payments. With the PUP, the self-employed can earn up to $€ 960$ over an eight-week period and still retain their full PUP entitlement. However, any move into employment by employees currently results in the removal of the PUP entirely. Such 'cliff edges' can result in very high 
marginal effective tax rates (METRs) ${ }^{27}$ and act as a strong disincentive for employment. Allowing recipients to keep part of their benefit when taking up work can have a significant positive effect on incentives to work. While the PUP is still in place, allowing both employees and the self-employed to retain some of their PUP payment for a period of time on their return to work could improve financial incentives to work.

\subsection{UNDEREMPLOYMENT AND IN-WORK SUPPORTS}

As a return to full employment is not anticipated in 2022 (McQuinn, et al., 2021) the line between 'working' and 'unemployment' may remain blurred as the economy recovers. Figure 4.2 shows the extent of this phenomenon during the Great Recession. The proportion of employees who reported working part-time (dark-blue line) was just over 15 per cent in 2006. Over the Great Recession, this figure rose to peak at nearly 22 per cent in 2013 before falling back to under 18 per cent by 2019. The light-blue line shows the proportion of these part-time workers who worked part-time involuntarily due to an inability to find a full-time job. Despite the modest increase in the part-time employment rate seen over the Great Recession, this masked a much more substantial rise in involuntary part-time employment; by 2013, 42 per cent of part-time employees reported working parttime as they could not find a full-time job, up from a low of 12 per cent in 2007. It is worth bearing in mind, however, that the labour market has tended to adjust quickly, with unemployment falling quickly as COVID-related economic restrictions reduce - so any rises in involuntary part-time employment may not be as longlasting as during the Great Recession. 


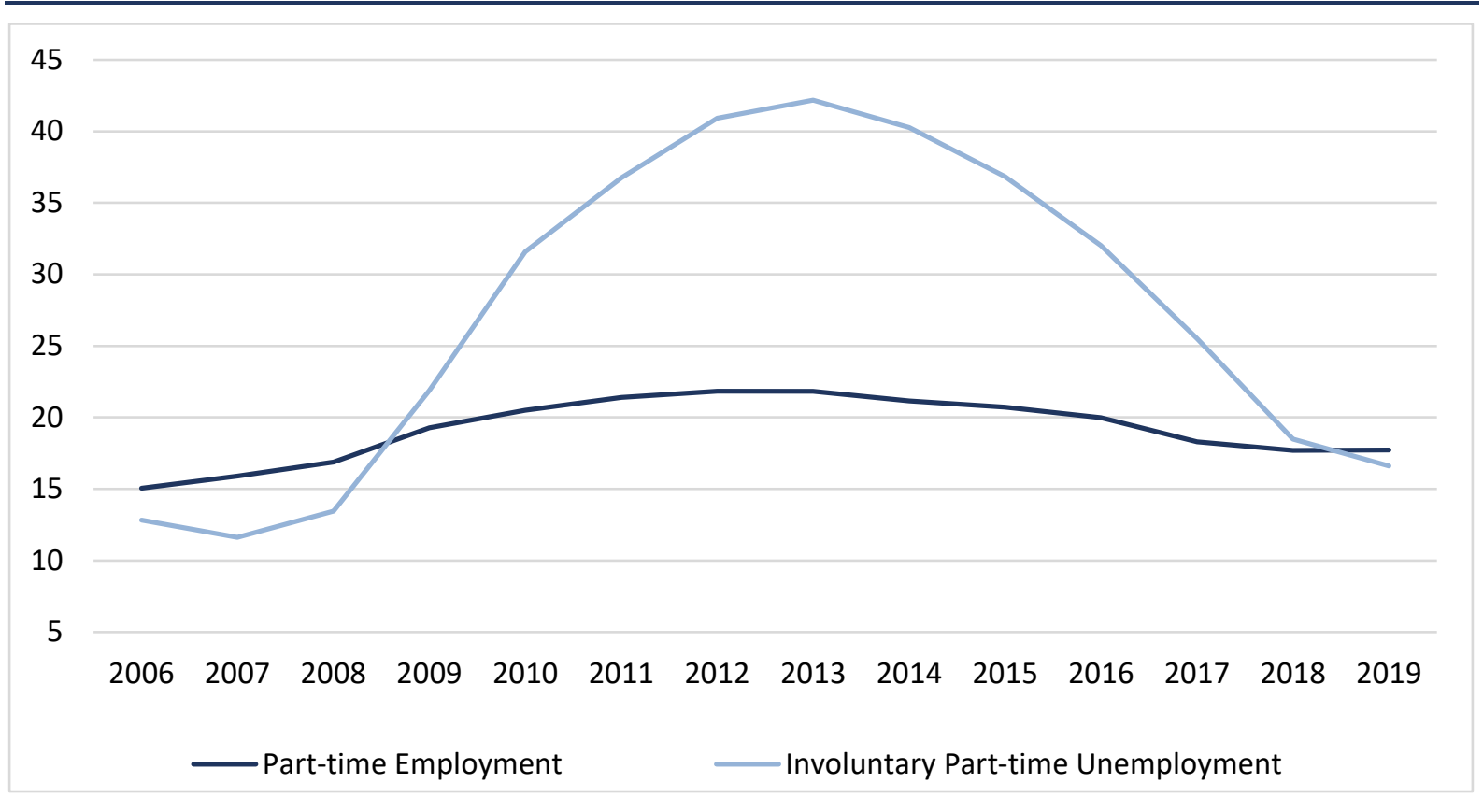

Source: Own calculations using the Irish Labour Force Survey.

Notes: 'Part-time employment' is the proportion of all those in employment who report working part-time hours. The 'Involuntary Parttime Unemployment' series shows the proportion of part-time employees who report working part-time due to an inability to find full-time employment.

A range of supports exist for those who involuntarily work reduced hours. One of these, the Short-Time Work Support (STWS), is discussed in Section 4.3. JSB and JSA are also available, not just to those fully unemployed, but also to those who are unemployed for four in seven consecutive days. If, however, an individual works part-time but spread over four or more days, they are not entitled to parttime unemployment supports. Two individuals working 15 hours a week for the same hourly pay, with one working these 15 hours in two days and another working three hours a day for five days a week, are not both eligible for JSB and JSA - only the former qualifies. This differs to the practice in place for other benefits such as the One Parent Family Payment (OPFP) and Disability Allowance, which are gradually reduced in line with earnings above a certain level. Identifying what days someone is working may be more difficult in the future if remote working continues to be a feature of work. The rule may also present constraints for employers wishing to have an adaptable workforce as we emerge from the recession.

The Working Families Payment (WFP) is also available to people at work on low incomes, but only to those with children. Table 3.1 indicates that working-age adults without children are at risk of significant income loss in the absence of the PUP and EWSS. Implicit social welfare weights reflect the 'value' that the social welfare system places on certain groups. Past research (Bargain and Keane, 2010; Bargain and Doorley, 2011) has shown that the weight for the lowest group of earners is particularly low compared to other income groups and could be 
increased by extending the current WFP scheme to childless individuals. This would also serve to increase financial incentives to work for low-paid individuals without children. This issue has also been highlighted by NESC (2020) and Roantree (2020), who point out that low-income adults without children are entitled to similar payments in other countries, such as the Working Tax Credit in the UK and Earned Income Tax Credit in the US.

Figure 4.3 shows the distributional effect of extending the WFP to childless individuals to provide this in-work benefit for those without children. We estimate the cost of this reform at $€ 206$ million per annum. The simulated reform slightly improves outcomes for those families in the lowest three income quintiles, with the largest improvement observed in the lowest income quintile.

FIGURE 4.3 DISTRIBUTIONAL EFFECT OF EMPLOYMENT LOSSES WITH AND WITHOUT COVID-19 POLICIES AND WFP REFORM

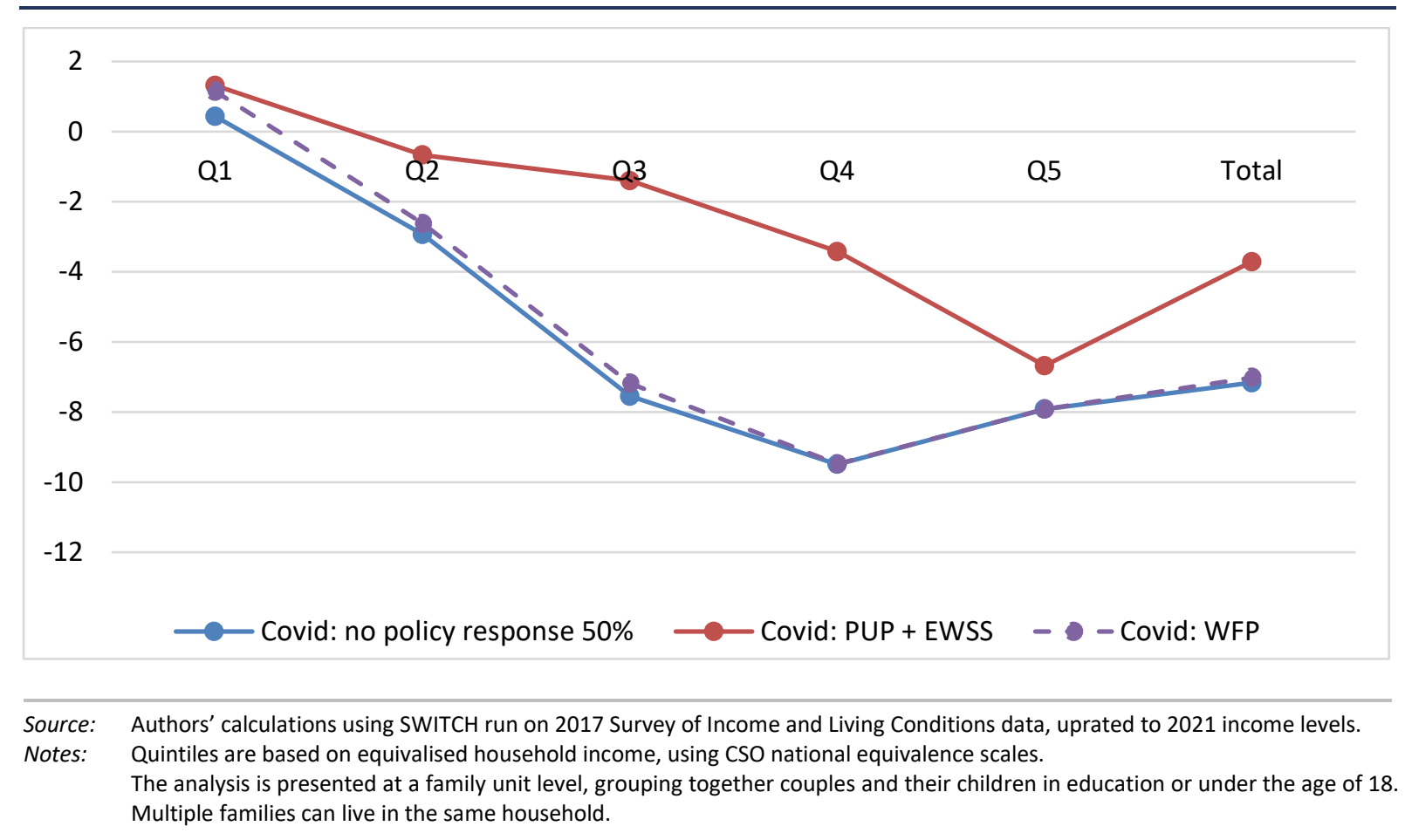

As shown in Table 3.1, of those who will lose income when PUP and EWSS are wound down, a high proportion of couples with children will also face income losses of over 20 per cent. Despite those on low incomes in this group being eligible for the WFP, the scheme has a well noted take-up problem. Since the scheme's inception in $1984,{ }^{28}$ a large number of eligible families appear to not take up their entitlement. Early estimates of take-up rates were as low as 13 per cent (Callan, et al., 1991). Campaigns aimed at raising awareness of the scheme were carried out during the 2000s and were found to improve take-up to around one-third of 
eligible families. ${ }^{29}$ However, Gray and Rooney (2018) in a comprehensive qualitative review of WFP recipients, indicate that take-up is still an issue. More recent estimates of WFP take-up would be useful to inform policymakers. If take-up remains an issue, efforts to increase the take-up rate further would be useful to boost the incomes and financial work incentives of low-earning families.

An alternative to the WFP, which operates through the Department of Social Protection and must be applied for, would be to consider a system of refundable tax credits. Employees and the self-employed currently receive tax credits but they are non-refundable. This means that, if a person's income is too low to incur a tax liability matching that of their tax credits, they use up only a partial amount of the credit. In countries with refundable tax credits the individual receives the full amount of the tax credit regardless of their tax liability. This is generally paid to recipients via the tax authority and may reduce stigma and the administrative burden of applying for the WFP. This may also help with the issue of low WFP takeup. The Earned Income Tax Credit scheme in the US, aimed at low-income workers, operates in this manner.

As we emerge from the pandemic, it may take time for firm and workers' incomes or work hours to recover. Assistance to those in part-time or low-paid employment will be important to maintain their standard of living but also to financially incentivise work.

\subsection{EMPLOYMENT SUBSIDIES AND SHORT-TIME WORK}

Most OECD countries have relied on job retention (JR) schemes to keep down unemployment and protect companies and incomes during the pandemic (OECD, 2020). As discussed in Section 2, as part of the COVID-19 policy response the Government introduced the TWSS, followed by the EWSS. A mix of scheme types are in operation across the OECD. Some countries opted for short-time work (STW) schemes which provide a direct subsidy for hours not worked; others, with little experience of STW schemes, such as Ireland, opted for wage subsidy schemes that subsidise employees at a rate that is linked to their prior earnings. Wage subsidies are typically paid to firms that experience a significant decline in revenue but, unlike in STW schemes, the size of the subsidy is typically independent of the decline in business activity. This increases the risk of deadweight losses whereby jobs that would have been retained in the absence of the subsidy are subsidised anyway. This is the case in Ireland where the EWSS pays a flat-rate subsidy per qualifying employee to companies whose turnover has fallen by 30 per cent. 
By May 2020, JR schemes supported around 50 million jobs across the OECD, more than ten times the amount during the Great Recession of 2008-2009 (OECD, 2020). Such schemes have an important role to play. They not only protect an individual's income but, unlike unemployment benefits, they keep a link between the worker and their employer even if work is not available at a point in time. This helps to reduce the likelihood of a worker exiting to unemployment and remaining there.

On the issue of withdrawing the EWSS, the OECD (2020) provides some policy guidance on how to withdraw such schemes and ensure that non-viable jobs do not continue to be supported in the longer run. Some of the OECD suggestions have been taken into account in recent months. These include:

- Avoiding too swift a withdrawal of such schemes but to have flexible timelimits on the wage subsidy scheme as the health and economic crisis evolves. This has been the practice in Ireland so far, as subsidy termination dates have been extended during the pandemic. The EWSS is currently set to be discontinued by 31 December 2021.

- The alignment of STW/wage subsidy payment rates with unemployment benefits. Since October 2020, the EWSS rates have matched those of the PUP, which helps to strengthen work incentives.

Other suggestions include:

- Gradually increasing the firm's contribution to the cost of hours not worked. Currently, firms availing of the EWSS can top up the salary of employees to a generous maximum amount. Following this OECD suggestion might involve stipulating a minimum top-up level or adjusting the subsidy based on the level of top-up paid.

- Providing support for job search and career guidance to help workers transition from subsidies to unsubsidised jobs, for example by registering workers on the EWSS with a Department of Social Protection (DSP) case officer.

- Promoting training while on reduced working hours, such as offering flexible training opportunities that can be combined with part-time work.

One option for Ireland as we emerge from the pandemic and wind down the EWSS would be to consider altering the existing STW scheme. STW schemes are widely used in Europe outside of the COVID-19 crisis. They allow employers to temporarily reduce the hours worked by employees to account for fluctuations in demand. Schemes of this type can be beneficial during economic downturns as they reduce layoffs and make it easier for companies to adjust their workers' hours without losing valuable human capital. The German Kurzarbeit scheme is often credited with helping to smooth Germany's labour-market adjustment during the Great Recession (Boeri and Bruecker, 2011). Evidence from Switzerland also indicates 
that the STW scheme in operation during the Great Recession improved firm survival rates. Siegenthaler and Kopp (2019) estimate that the longer-term unemployment benefit savings are likely to have been large enough to cover the STW scheme cost. However, there are also some downsides associated with STW schemes. Because jobs are retained when there is less output demand, the schemes hinder the reallocation of labour to more productive jobs. They can also limit labour-market access for temporary and part-time workers as they are typically limited to permanent employees.

The Irish Short-Time Work Incentive scheme provides income support to people who have temporarily been placed on a shorter working week by their employer. It is similar to part-time JSB except that the benefit is not taxed. It is effectively part of the unemployment benefits system - while in most other countries it is entirely separate - and the scheme is not widely used (Lydon, et al., 2019).

Take-up rates for STW schemes tend to be strongly affected by how generous the schemes are to employers and employees (Boeri and Bruecker, 2011). For example, workers receive 60 per cent of lost net earnings (or 67 per cent for workers with children) through the German Kurzarbeit scheme. With median weekly earnings at $€ 845$ per week in Q4 of 2020, the Irish STW scheme - which is paid as a proportion of the maximum weekly rate of JSB, depending on the number of days of work lost - is unlikely to provide this generosity for many claimants. In a recent Parliamentary Question, the Minister for Social Protection acknowledged:

In a period where we expect demand to recover in many sectors but still remain lower than it was immediately before the pandemic, there is scope for a short-time work support scheme to help employers rehire staff that were temporarily laid-off rather than to make them redundant ${ }^{30}$

and indicated that funding had been made available for increasing employment services to workers. The Department of Social Protection and Department of Finance are currently looking at designing and implementing a new STW scheme as part of this funding. The generosity of the scheme will be an important factor in its take-up.

\subsection{SUPPORTS FOR STUDENTS}

Quintini (2013) discusses how combining work and study can help young people develop skills needed in the job market and help with the transition from education to employment. This piece of research shows that, compared to the OECD average of 39 per cent, Ireland had a slightly lower proportion of students (aged 16-29) 
combining work and study. However, Ireland did stand out in having a very low proportion engaging in work that is very closely linked to their studies - the closer this link, the likely higher benefit for post-education employment. In countries like Austria, France, Germany and Denmark, more than half of students combining work and study did so through apprenticeships or vocational education and training, where the education and employment would be in similar fields. In Ireland less than one quarter of those combining education and work did so under such schemes. Combining employment and study, particularly where the two are not linked or due to economic necessity, may have negative repercussions for students. According to a survey carried out by the Irish League of Credit Unions prior to the pandemic (April 2019), 74 per cent of third-level students reported working to cover costs; 55 per cent reported missing lectures to work while 60 per cent reported that work had a negative impact on their studies. On average, students reported working 15 hours per week. ${ }^{31}$ Evidence from the Growing Up in Ireland survey supports this: 44 per cent of 20-year-olds surveyed between 2018 and 2019 at least partly funded their education through employment (Growing Up in Ireland, 2019).

As shown in Table 3.1, 13 per cent of those in education would have lost income due to COVID-related job losses if supports such as the PUP had not been introduced. Of those experiencing an income shock, 82 per cent would have lost 20 per cent or more of their income, largely because they were not eligible for the pre-existing unemployment supports. As the intention is to withdraw the PUP for students in September 2021, many students may return to employment as they continue their studies. However, employment opportunities may take time to return as the economy recovers, particularly in the hardest-hit sectors, such as hospitality, which traditionally provide part-time employment options for students. Figure 2.1 illustrates this phenomenon; youth unemployment remained elevated for a number of years after the Great Recession. It is important to bear in mind that only students who lost their jobs due to COVID can receive PUP; as the pandemic has continued for over a year, students starting third-level education in September 2020 are likely to have struggled to find employment as a result of the pandemic but would not be eligible for the PUP. This section explores other income supports available to students and discusses potential policy reforms.

As discussed in Mooney et al. (2010), financial support plays an important role in retaining students in education. Those in receipt of a maintenance grant have higher progression rates than those not in receipt. This has also been found to be true internationally, with dropout rates lower for those in receipt of financial support. ${ }^{32}$ The Student Grant Scheme, the main financial support available for 
third-level students in Ireland, consists of a 'fee grant' and 'maintenance grant'. As the names suggest, the fee grant covers tuition fees while the maintenance grant is intended to cover living costs. Aside from independent mature students, who are assessed based on their own/cohabitant's income, student grant entitlements are generally based on their parental income. Grant rates differ depending on parental income; the full maintenance grant rate stands at $€ 3,025$ while there is a 'special rate' of $€ 5,915$ for the very lowest income group. ${ }^{33}$ According to Phulphagar and Kane (2020), 37 per cent of all students in higher and further education received some level of a grant, with 40 per cent receiving the full maintenance grant and 30 per cent receiving the 'special rate' grant. As shown in Phulphagar and Kane (2020), in recent years the numbers of students qualifying for a grant has fallen, despite a rise in third-level attendance overall. This is likely, in part, because income thresholds for the grant have tended to remain static for long periods despite incomes rising over this time. ${ }^{34}$

Grant rates differ depending on whether the student's family home is within 45 kilometres of the college they are attending (adjacent/non-adjacent rate) and with family income. McCoy et al. (2010) point out that, in the early 1970s, the nonadjacent rate of the student grant was roughly equal to the rate of Unemployment Assistance (UA, now JSA). This benefit can be seen as a standard, basic minimum income level. The ratio changed greatly over the following decades so that, by 2006, the UA rate was seven times higher than the non-adjacent grant rate, reflecting a failure to increase the rates in line with inflation. In more recent years, this ratio has dropped, not due to increases in the grant but due to the large cuts to JSA for the under-25s (discussed in Section 4.1).

Table 4.1 shows the rates of maintenance grant for 2021 and how these rates compare to the annual amount that can be received in JSA. For those in receipt of the non-adjacent rate, it is generally assumed that they will not be able to reside in the family home during term-time. We use, as point of comparison for this group, the full rate of JSA, as unemployed youths aged 18-24 and living independently (in receipt of housing benefits) are entitled to the maximum JSA rate of $€ 203.40$ per week. We compare the adjacent grant rate to the 'youth' JSA rate - i.e. the rate of $€ 112.40$ received by those under 25 not living independently. For those in receipt of the 'special rate' (i.e. those whose means are the lowest), the

These are the full and special rates for those whose parental home is more than 45 kilometres from the college attended, known as the 'non-adjacent' rate. The rates fall to $€ 2,375$ for the 'special rate' and $€ 1,215$ for the 'full maintenance' rate for those whose parental home is within a 45 kilometre radius (adjacent rates). To qualify for the special rate, total household reckonable income must not exceed $€ 24,500$ and the household must be in receipt of a long-term social welfare payment. For comparison, we estimate that the cut-off disposable income for households to belong to the lowest income quintile is $€ 20,460$. 
grant represents between 40 per cent and 56 per cent of the JSA rate. This falls to 21-29 per cent for those in receipt of the 'full maintenance' rate.

TABLE 4.1 MAINTENANCE GRANT RATES, 2021

\begin{tabular}{|c|c|c|c|c|}
\hline & & & \multicolumn{2}{|c|}{ Grant as proportion of JSA } \\
\hline Type & $\begin{array}{l}\text { Non-adjacent } \\
\text { rate }\end{array}$ & Adjacent rate & $\begin{array}{c}\text { Non-adjacent: } \\
\text { Full JSA rate } \\
\%\end{array}$ & $\begin{array}{c}\text { Adjacent: }<25 \text { JSA } \\
\text { Rate } \\
\%\end{array}$ \\
\hline Special rate & $€ 5,915$ & $€ 2,375$ & 56 & 40 \\
\hline Full maintenance & $€ 3,025$ & $€ 1,215$ & 29 & 21 \\
\hline Part maintenance (75\%) & $€ 2,270$ & $€ 910$ & 21 & 15 \\
\hline Part maintenance (50\%) & $€ 1,515$ & $€ 605$ & 14 & 10 \\
\hline Part maintenance (25\%) & $€ 755$ & $€ 305$ & 7 & 5 \\
\hline
\end{tabular}

Source: Authors' calculations.

One option available to policymakers is a more gradual tapering of the PUP, which could help students maintain a certain standard of living while searching for work and help prevent drop-out rates from rising. Further options include extending other jobseeker supports to students or increasing the generosity of student grants; for example, in other OECD countries such as Australia and Sweden meanstested benefits received while in education have a rate equivalent to those of unemployment benefits. An independent review of the student grant scheme is currently underway. ${ }^{35}$ 


\section{SECTION 5}

\section{Conclusions}

The COVID-19 pandemic has had a large and negative impact on the Irish economy and the incomes of Irish workers as widespread job losses occurred. The Government responded by introducing two main income supports: the PUP and EWSS. Were it not for these policies, we estimate that pandemic-related unemployment would have resulted in an average drop in disposable incomes of 7 per cent. The pre-existing social welfare system would have acted in a progressive manner, sheltering the incomes of the lowest income group, with losses sharpest in the higher income quintiles.

With the introduction of the PUP and the EWSS, we estimate that the average income loss due to COVID-related job losses was more than halved, to 3 per cent. The bottom income quintile actually gained, on average, experiencing a rise in income of nearly 2 per cent. This reflects the relatively generous nature of the PUP, compared to pre-existing jobseeker supports. Average income losses further up the income distribution ranged from 1 per cent in quintile 2 to 6 per cent in quintile 5 .

The availability of the PUP, while strengthening income supports for those in the middle and upper parts of the income distribution, weakens financial incentives to work. Despite this, 85 per cent of those we simulate to have lost their job due to the pandemic have an RR of 75 per cent or less, meaning there are still financial gains to be made from working. Indeed, previous ESRI research has shown that financial work incentives are just one factor in labour supply decisions. Among those with very weak financial incentives to work, most are actually in employment anyway.

Despite having pre-existing income support schemes such as JSB, JSA and the STWS, it was deemed necessary to implement additional income protection schemes, at more generous rates, in response to the crisis. Given that the PUP and EWSS are soon to be withdrawn, we explored the reasons why such schemes were needed in the first place and the groups most at risk of significant income loss when they are withdrawn. Those in the 18-24 age category and students are particularly likely to lose a significant proportion of their income when the schemes are wound down, if ample employment opportunities are not available. This finding is driven by the fact that students are eligible for PUP, but not the pre-existing unemployment payments. Those aged under 25 and not in education are eligible for JSA but at a rate 45 per cent lower than that of those over 25 . We discussed potential policy options to protect these groups, including the alignment of maintenance grant rates with JSA rates and a more gradual tapering of the PUP to 
allow the labour market to recover more fully before its withdrawal. We also simulated aligning the under- 25 and over- 25 JSA rates and found that it would have a substantial positive impact on income in the lowest income quintile.

Working-age childless singles and childless couples are also at risk of a large income shock when these schemes are withdrawn. The Irish Working Families Payment (WFP) improves the financial incentive to work by providing a payment to lowincome workers who satisfy certain work and income criteria. It also helps to protect the income of those who cannot find full-time work. The WFP is currently available only to families with children, however. We examined the impact of extending the WFP to low-income singles and couples without children and found that it would increase the incomes of those in the lowest three income quintiles, with the largest improvement observed in the lowest income quintile. Such a move would also improve the financial work incentives of these groups. Working-age couples with children also face significant losses when the PUP and EWSS are withdrawn. For those currently eligible for WFP, there has been a long-running problem with take-up of the scheme. Further efforts to increase take-up would assist this group.

As we emerge from the pandemic, it may take time for firms' and workers' incomes or work hours to recover. Assistance to those in part-time or low-paid employment will be important to maintain their standard of living, but also to financially incentivise work. An option that has proved successful internationally would be to allow recipients of PUP retain some of their payment as they return to work. At the moment, the benefit is fully withdrawn if any employment income is received. We highlighted other issues in the social welfare system that may negatively affect incentives to work. The current JSA rule that requires a person to be unemployed for four consecutive days in seven may present an unnecessary rigidity in the system and could be replaced by an income disregard, as is the case with other benefits.

Wage subsidies have played an important role in keeping workers linked to their employers over the pandemic. The Government has already followed OECD suggestions to act in a flexible manner regarding the withdrawal of schemes such as the EWSS and to align the subsidy rate with those of the PUP. Further recommendations from the OECD suggest winding the scheme down slowly while providing job search assistance and training opportunities to those in unviable subsidised jobs. Generous short-time work schemes, such as those in operation in Germany and Switzerland, have been shown to significantly protect employment during downturns. Reform to the Irish STW scheme's generosity, which is not widely taken up, may provide a suitable, flexible alternative to wage subsidies when the EWSS is fully withdrawn. 


\section{REFERENCES}

Almeida, V., S. Barrios, M. Christl, S. De Poli and A. Tumino (2020). 'Households' income and the cushioning effect of fiscal policy measures during the Great Lockdown', JRC Working Papers on Taxation \& Structural Reforms, Issue 2020-06.

Bargain, O. and K. Doorley (2011). 'Caught in the trap? Welfare's disincentive and the labor supply of single men', Journal of Public Economics, 95(9).

Bargain, O. and K. Doorley (2011). 'In-Work Transfers in Good Times and Bad: Simulations for Ireland', Research in Labour Economics, Vol. 33.

Bargain, O. and K. Doorley (2017). 'The Effect of Social Benefits on Youth Employment: Combining Regression Discontinuity and a Behavioral Model', Journal of Human Resources, 52(4).

Bargain, O. and C. Keane (2010). 'Tax-Benefit-revealed Redistributive Preferences Over', LABOUR, pp. 141-167.

Beirne, K., K. Doorley, M. Regan, B. Roantree and D. Tuda (2020). 'The potential costs and distributional effect of COVID-19 related unemployment in Ireland', Budget Perspectives, Issue 202101.

Bettinger, E. (2004). 'How Financial Aid Affects Persistence', s.l.: NBER Chapters, in College Choices: The Economics of Where to Go, When to Go, and How to Pay For It, pp. 207-238, National Bureau of Economic Research, Inc.

Boeri, T. and H. Bruecker (2011). 'Short-time work benefits revisited: Some lessons from the great recession', Economic Policy.

BSA (2020). British Social Attitudes 37, s.I.: s.n.

Cahill, B. and R. Lydon (2021). The Impact of COVID-19 on the incomes and debt sustainability of Irish Households, Dublin: Central Bank of Ireland Economic Letter.

Callan, T., B. Nolan, B. Whelan and D. Hannan (1991). Poverty, Income and Welfare in Ireland, s.I.: Economic and Social Research Institute.

Cantó Sánchez, O., F. Figari, C. Fiorio and S. Kuypers (2021). 'Welfare resilience at the onset of the COVID-19 pandemic in a selection of European countries: impact on public finance and household incomes', EUROMOD Working Paper Series, Issue $\mathrm{EM} 4 / 21$.

CSO (2020). https://www.cso.ie/en/releasesandpublications/er/mue/monthlyunemploy mentoctober2020/. s.l.: s.n.

CSO (2021). https://www.cso.ie/en/releasesandpublications/fp/fp-c19isar/covid19incomesupports-

ananalysisofrecipientsmarch2020tomay2021/backgroundnotes/.

Doorley, K., C. Keane, A. McTaugye, S. O'Malley, M. Regan, D. Roantree and D. Tuda (2020). 'Distributional Impact of Tax and Welfare Policies: COVID-related policies and Budget 2021', Quarterly Economic Commentary: Special Articles.

Doorley, K., D. Sologon and C. O'Donoghue (2021). 'The Gender Gap in Income and the COVID-19 Pandemic', IZA DP No. 14360. 
Doris, A., D. O'Neill and O. Sweetman (2020). 'Does Reducing Unemployment Benefits during a Recession Reduce Youth Unemployment?: Evidence from a 50 Percent Cut in Unemployment Assistance', Journal of Human Resources.

Gray, J. and C. Rooney (2018). Supporting low income working families: Enabling resilience., s.I.: MUSSI Working Paper Series.

Growing Up in Ireland (2019). Key Findings: Cohort '98 at 20 years old in 2018/19. Education, Training and Employment., s.l.: s.n.

Lassibille, G. and L. Gomez (2008). 'Why Do Higher Education Students Drop Out? Evidence from Spain', Education Economics, Vol. 16, No. 1, pp. 89-105.

Lydon, R., T. Mathä, S. Millard (2019). Short-time work in the Great Recession: Firm-level evidence from $20 \mathrm{EU}$ countries, Dublin: Central Bank of Ireland.

McCoy, S., E. Calvert, E. Smyth and M. Darmody (2010). Study On The Costs Of Participation In Higher Education, s.l.: Higher Education Authority..

McQuinn, K., C. O'Toole, I. Kostarakos and C. Coffey (2021). Quarterly Economic Commentary, Spring 2021, Dublin: ESRI.

Mooney, O., V. Patterson, M. O'Connor and A. Chantler (2010). A Study of Progression in Irish Higher Education, s.l.: Higher Education Authority.

NESC (2020). The Future of the Irish Social Welfare System: Participation and Protection, s.l.: s.n.

O'Donoghue, C., D. Sologon and I. Kyzyma (2021). 'Novel welfare state responses in times of crises: COVID-19 Crisis vs. the Great Recession', Working Papers 573, ECINEQ, Society for the Study of Economic Inequality.

O'Donoghue, C., D. Sologon, I. Kyzyma and J. McHale (2020). 'Modelling the Distributional Impactof the COVID-19 Crisis', Fiscal Studies, 41(2).

OECD (2020). Job retention schemes during the COVID-19 lockdown and beyond, Paris: OECD.

OECD (2021). Risks that matter 2020: The long reach of COVID-19, Paris: OECD.

OECD (2021). Supporting jobs and companies: A bridge to the recovery phase. Paris: OECD.

OECD (2021). Supporting jobs and companies: A bridge to the recovery phase. Paris: OECD.

Phulphagar, R. and F. Kane (2020). Social Impact Assessment Series Student Grant Scheme, s.I.: DPER.

Quintini, G. (2013). Working and Leanring: A Diversity of Patterns. OECD Social, Employment and Migration Working Paper No. 169.

Roantree, B. and T. Kakoulidou (2021). Options for raising tax revenue in Ireland, s.I.: ESRI Budget Perspectives paper I.

Roantree, B. (2020). Understanding Income Inequality in Ireland. Journal of the Statistical and Social Inquiry Society of Ireland. 
Roantree, B., B. Maître, A. McTague I. Privalko (2021). Poverty, Income Inequality And Living Standards In Ireland. Dublin: ESRI.

Savage, M., T. Callan and J. Walsh (2015). 'A Profile of Financial Incentives to Work in Ireland', s.I.: Journal of the Statistical and Social Inquiry Society of Ireland, Vol. XLIV.

Siegenthaler, M. and D. Kopp (2019). Short-Time Work and Unemployment in and after the Great Recession, s.I.: KOF Swiss Economic Institute, ETH Zurich.

Sologon, D., C. O'Donoghue, I. Kyzyma and J. McHale (2020). 'Modelling the Distributional Impact of the COVID-19 Crisis', Fiscal Studies, 41(2).

Stephens, R. (2005). Universal or Targeted: a Comparison of Poverty Programmes, s.l.: The Policy Institute, Trinity College.

Tetlow, G., T. Pope and G. Dalton (2020). 'Coronavirus and unemployment. The importance of government policy: a five nation comparison', IFG Insight. 



\section{APPENDIX}

TABLE A.1 PUP AND JSB RATES

\begin{tabular}{c|c|c|c}
\hline $\begin{array}{c}\text { Average Weekly } \\
\text { Earnings }\end{array}$ & PUP & $\begin{array}{c}\text { Average Weekly } \\
\text { Earnings }\end{array}$ & JSB \\
\hline$<€ 200$ & $€ 203$ & $<€ 150$ & $€ 91.10$ \\
$>€ 200,<€ 300$ & $€ 250$ & $>€ 150,<€ 220$ & $€ 131$ \\
$>€ 300,<€ 400$ & $€ 300$ & $>€ 220,<€ 300$ & $€ 159$ \\
$>€ 400$ & $€ 350$ & $>€ 300$ & $€ 203$ \\
\hline
\end{tabular}

Notes: Based on a single person with no adult or child dependants. No IQA or IQC is payable to PUP recipients. Those earning up to $€ 300$ before becoming unemployed can receive a maximum of 87.20 for an adult dependant, rising to $€ 134.70$ for those earning over $€ 300$ before becoming unemployed. 
Whitaker Square,

Sir John Rogerson's Quay,

Dublin 2

Telephone +35318632000

Email admin@esri.ie

Web www.esri.ie

Twitter @ESRIDublin 